\title{
An Extracellular Perspective on CNS Maturation: Perineuronal Nets and the Control of Plasticity
}

\author{
Daniela Carulli ${ }^{1,2, *}$ and Joost Verhaagen ${ }^{1}$ \\ 1 Laboratory for Neuroregeneration, Netherlands Institute for Neuroscience, Royal Academy of Arts and \\ Sciences, 1105 BA Amsterdam, The Netherlands; j.verhaagen@nin.knaw.nl \\ 2 Department of Neuroscience Rita Levi-Montalcini and Neuroscience Institute Cavalieri Ottolenghi, \\ University of Turin, 10040 Turin, Italy \\ * Correspondence: d.carulli@nin.knaw.nl
}

check for updates

Citation: Carulli, D.; Verhaagen, J. An Extracellular Perspective on CNS Maturation: Perineuronal Nets and the Control of Plasticity. Int. J. Mol. Sci. 2021, 22, 2434. https://doi.org/ $10.3390 /$ ijms 22052434

Academic Editors: Luca Bonfanti and Sebastien Couillard-Despres

Received: 15 January 2021

Accepted: 24 February 2021

Published: 28 February 2021

Publisher's Note: MDPI stays neutral with regard to jurisdictional claims in published maps and institutional affiliations.

Copyright: (c) 2021 by the authors. Licensee MDPI, Basel, Switzerland. This article is an open access article distributed under the terms and conditions of the Creative Commons Attribution (CC BY) license (https:// creativecommons.org/licenses/by/ $4.0 /)$.

\begin{abstract}
During restricted time windows of postnatal life, called critical periods, neural circuits are highly plastic and are shaped by environmental stimuli. In several mammalian brain areas, from the cerebral cortex to the hippocampus and amygdala, the closure of the critical period is dependent on the formation of perineuronal nets. Perineuronal nets are a condensed form of an extracellular matrix, which surrounds the soma and proximal dendrites of subsets of neurons, enwrapping synaptic terminals. Experimentally disrupting perineuronal nets in adult animals induces the reactivation of critical period plasticity, pointing to a role of the perineuronal net as a molecular brake on plasticity as the critical period closes. Interestingly, in the adult brain, the expression of perineuronal nets is remarkably dynamic, changing its plasticity-associated conditions, including memory processes. In this review, we aimed to address how perineuronal nets contribute to the maturation of brain circuits and the regulation of adult brain plasticity and memory processes in physiological and pathological conditions.
\end{abstract}

Keywords: perineuronal net; critical period; chondroitin sulfate proteoglycans; learning; memory; Alzheimer's disease; drug addiction

\section{Introduction}

During postnatal development the continuous interaction between the individual and the environment affects the formation and refinement of neural networks. Neuronal circuits that are activated by environmental stimuli are strengthened, whereas unused synapses are eliminated. The experience-dependent shaping of neuronal connections allows individuals to best adapt to the world around them. The ability of brain connections to change in response to experience, i.e., plasticity, is particularly high during discrete time windows of postnatal development, called critical periods. Different critical periods, each one with its own timings, involve distinct brain regions across development. For example, in many species, including humans, critical periods exist for the development of sensory systems, vocal behavior, cognitive functions, and emotional traits. The development of higher functions, such as language, may depend on the proper temporal alignment of critical periods for the development of lower functions [1]. Since the pioneering studies by Hubel and Wiesel in the 1960s, the best-characterized model of critical period plasticity is ocular dominance (OD) plasticity. In the adult primary visual cortex, neurons that respond preferentially to inputs from one eye or the other are organized in alternating stripes that run perpendicularly to the cortical surface (so-called OD columns). During the critical period for OD plasticity, geniculocortical afferents serving the two eyes are initially completely overlapping, and only an activity-driven competition between the two eyes leads to the subsequent segregation of the afferents in separate columns. However, if inputs from one eye are reduced (due for instance to strabismus, congenital cataract or other conditions of monocular deprivation), there is a shift in the responsiveness of visual 
cortex neurons toward the dominant eye, with the concomitant remodeling of cortical dendritic spines and thalamic axons, which is accompanied by a loss of visual acuity in the weaker eye [2-6]. These deficits are permanent if monocular deprivation is not corrected before the closure of the critical period. In fact, the end of critical periods brings about a progressive stabilization of synaptic connections and, consequently, a drastic reduction in brain plastic abilities. Experiments in the visual system made it clear that critical periods can also represent a time of vulnerability for the developing brain. If aberrant or deficient stimuli are experienced, maladaptive plasticity takes place and adverse sensory outcomes manifest with lifelong consequences. This also holds true for the consequences of early-life adversity (e.g., childhood trauma, stress, impoverished care) on the risk of developing cognitive deficits or psychopathologies in adult individuals [7].

The onset and closure of critical periods are strictly controlled by a number of molecular and cellular mechanisms. In primary sensory areas the onset for plasticity is triggered by a change in the balance between excitation and inhibition. This change is mainly due to the maturation of intracortical GABAergic neurons, especially fast-spiking, parvalbuminexpressing $(\mathrm{PV}+)$ basket cells. These neurons, which form a highly interconnected network, inhibit nearby pyramidal cells and generate gamma frequency rhythmic oscillations, which are important for information processing. Notably, PV circuits mature at different times across brain regions, contributing to a sequential appearance of critical periods. Although the maturation of PV cells depends on an intrinsic genetic program $[8,9]$, it is sensitive to experience. Dark rearing disrupts the maturation of inhibitory circuits [10], whereas enriched environmental stimulation accelerates it [11-13]. Neural activity drives the release of developmental regulators, which promote PV neuron maturation, including brain-derived neurotrophic factor (BDNF) [14], neuronal pentraxins (NARP) [15], neuregulins [16], and orthodenticle homeobox 2 (Otx2) [17].

Several mechanisms are involved in the termination of a critical period. One mechanism that stands out is the formation of perineuronal nets (PNNs). In this review, we address the role of PNNs in restricting critical period plasticity. Next, we discuss the modulation of PNNs during adult brain plasticity, including learning and memory. Finally, we describe the involvement of PNNs in memory-related diseases, including Alzheimer's disease and drug addiction.

\section{PNNs and Brain Maturation}

\subsection{Distribution of PNNs}

PNNs are condensed aggregates of an extracellular matrix (ECM) enwrapping the cell body, dendrites, and axon initial segments of several neurons in the adult central nervous system (CNS). They represent one form of an ECM in the CNS, together with the ECM that is loosely distributed in the parenchyma, the ECM that constitutes the basal lamina (which separates the CNS tissue from meningeal and vascular tissues), and the ECM that is located at the nodes of Ranvier [18]. The PNN coating is interrupted by holes, in which synaptic boutons are contained (see Figure 1A,B for representative pictures of PNNs in the mouse cerebellar nuclei that enwrap GABAergic terminals).

Therefore, these synapses can be viewed as a tetrapartite structure, comprising the presynaptic terminal, the postsynaptic element, astrocytic processes, and the PNN [19]. PNNs are found around distinct classes of inhibitory and excitatory neurons throughout the rostrocaudal axis of the CNS of vertebrates, from the cortex to the spinal cord. PNNs are particularly well developed in birds and mammals. In the latter class, PNNs have been described in several species, including mice, rats, guinea pigs, gerbils, cats, dogs, sheep, monkeys, and humans. Examples of PNN-bearing neurons in rodents are GABAergic $\mathrm{PV}+$ neurons in the cortex, interneurons, and pyramidal neurons in the hippocampus; PVpositive and negative neurons in the striatum; excitatory neurons in the cerebellar nuclei; motoneurons and interneurons in the spinal cord [20-35]. Notably, species-dependent differences exist with respect to whether PNNs surround the inhibitory or excitatory neurons. Although in rodents, the majority of PNN-enwrapped neurons in the cortex are 
$\mathrm{PV}+\mathrm{GABAergic}$ neurons, in primates, a substantial number of pyramidal neurons in the motor and somatosensory cortex bear a PNN $[24,36,37]$. In the basolateral amygdala of rats, PNNs are found around PV+ and PV - neurons, while in mice, they are reported only around excitatory neurons [38,39]. The common denominator of all different types of PNNbearing neurons seems to be their fast-spiking neuronal activity. Thus, PNNs are proposed to serve as extracellular reservoirs for physiologically relevant cations, such as $\mathrm{Ca}^{2+}, \mathrm{K}^{+}$, or $\mathrm{Na}^{+}$, contributing to fast and precise neuronal transmission [40]. Indeed, through ionic interactions, polyanionic components of PNNs are able to reversibly accumulate cationic molecules at physiological concentrations, potentially contributing to local molecular gradients of ions [41]. The "anionic shield" made by the PNN may also represent a protective mechanism against toxic species that are generated by metabolic or oxidative stress, as discussed later.
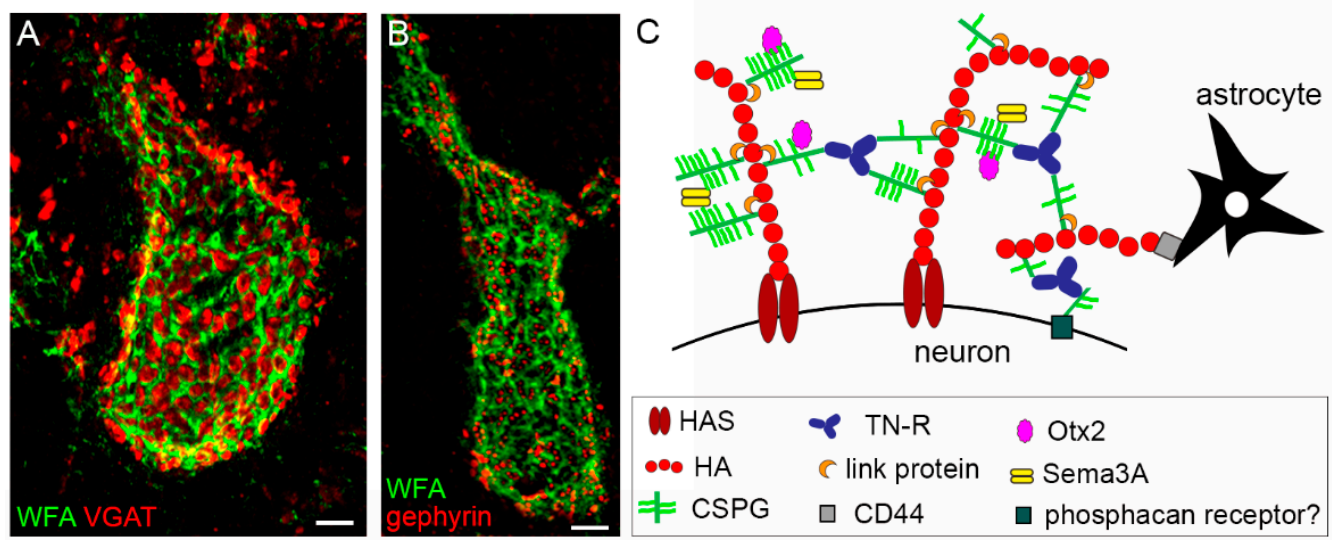

Figure 1. Structure and composition of the PNN. (A,B) show PNNs around neurons in the mouse cerebellar nuclei, labelled by Wisteria floribunda agglutinin (WFA), in green. PNNs display their typical holes, in which pre-synaptic terminals are contained. In (A), GABAergic terminals are shown (in red), labelled by anti-VGAT antibodies. In (B), post-synaptic clusters of gephyrin, which anchors GABA receptors to the underlying cytoskeleton, are shown (in red). In (C), the main molecular components of PNNs are depicted. Scale bar: $4 \mu \mathrm{m}$ in $(\mathbf{A}, \mathbf{B})$.

\subsection{Composition of the PNN}

PNNs are primarily composed of hyaluronan, chondroitin sulfate proteoglycans (CSPGs), link proteins and tenascin-R. Hyaluronan can be considered the backbone of the PNN structure (Figure 1C). It is a large polymer of disaccharide units (made of Nacetylglucosamine and glucuronic acid), to which CSPGs can bind [42]. Hyaluronan is synthesized by hyaluronan synthases (HAS). These are plasma membrane-bound enzymes, mainly expressed by neurons, which extrude hyaluronan into the extracellular space. While being synthesized, hyaluronan can be kept anchored to the cell surface via the HASs [27,43]. HAS may thus represent the anchoring sites of the PNN to the neuronal membrane, although the hyaluronan receptor CD-44, which is mainly expressed by astrocytes [44], may also contribute to keeping the PNN in place near the synapses. Three HAS isoforms exist (HAS-1, -2, -3), the expression of which varies depending on the CNS region and developmental time point $[27,29,45]$. Hyaluronan is crucial for PNN assembly, as shown by the complete removal of PNNs following the administration of hyaluronidase [46-48].

CSPGs bind to hyaluronan (via their N-terminal domain) and consist of a core protein and a number of chondroitin sulfate glycosaminoglycan chains (CS-GAG) attached to it. The CSPGs found in the PNN are the members of the lecticans family (aggrecan, neurocan, brevican, versican) and receptor protein tyrosine phosphatase zeta (RPTP $\zeta$ )/phosphacan. They are synthesized by neurons and/or glial cells [27,29,49]. Depending on which CSPGs are present, heterogeneity in the PNN composition exists within and between CNS regions [26,29], although aggrecan seems to be present in the majority of the PNNs. CSGAG are made of alternating disaccharide units of N-acetylgalactosamine (GalNAc) and 
glucuronic acid, which can be nonsulfated or sulfated at various positions, typically in position 2 of glucuronic acid and position 6 of GalNAc (CS-D), positions 4 and 6 of GalNAc (CS-E), position 4 of GalNAc (CS-A), or position 6 of GalNAc (CS-C) [50]. By affecting the charge properties of the CS chains and therefore their binding properties, different patterns of sulfation significantly impact CSPG function. Interestingly, the sulfation pattern of CS-GAG in the PNN differs from those of the diffuse matrix, giving PNNs unique binding properties $[46,51,52]$. However, there is also diversity in the sulfation pattern of different PNNs [53]. Moreover, the pattern of the CS sulfation changes considerably over development. While most of the CS is 6-sulfated in the embryonic brain, at birth, only $18 \%$ of the CS is 6-sulfated and $60 \%$ are 4 -sulfated. These amounts change again after the end of the critical period, when $2 \%$ of the CS is 6-sulfated and $91 \%$ is 4 -sulfated $[46,54,55]$. In the aged rodent brain, most of the remaining 6-sulfation is removed [56]. These differences are important because CS-A and CS-C have distinct binding properties and influence axon growth and plasticity in opposite ways, with CS-C promoting it and CS-A inhibiting it $[51,57-59]$. Notably, the sulfation pattern of PNN CS-GAGs is different from that of the general brain matrix. For instance, CS-E, which is very inhibitory to axon growth, represents $1.4 \%$ of the CS in the diffuse ECM and 2.1\% in the PNNs [46]. CS-E can also bind some growth and plasticity regulators, including semaphorin $3 \mathrm{~A}$ (Sema3A) and orthodenticle homeobox 2 (Otx2) [60-63].

Link proteins stabilize the binding between CSPGs and hyaluronan (Figure 1C). The link protein family comprises four members, with three of them expressed in the CNS: cartilage link protein-1/Hapln1, brain link protein-1 (Bral1)/Hapln2 and Bral2/Hapln4 [64-67]. Cartilage link protein-1 and Bral2 are expressed in PNNs, whereas Bral1 is abundant in the ECM surrounding the nodes of Ranvier [68].

The lecticans are linked to each other via the trimeric glycoprotein tenascin- $\mathrm{R}$, which binds to the lectican C-terminal domain [69] (Figure 1C). As demonstrated by the reduced or diffuse expression of several PNN components in adult mice lacking tenascin- $\mathrm{R}$, this molecule plays a crucial role in PNN assembly [70,71].

PNNs are formed during postnatal development. However, many PNN components, particularly hyaluronan and CSPGs, are expressed at embryonic or postnatal stages when PNNs have not yet developed [72-74]. What brings them together to form a PNN? Analysis of the temporal and spatial distribution of major PNN components at the mRNA and protein levels revealed that link proteins might fulfill the role of PNN organizers, being expressed in neurons surrounded by PNNs exactly at the time of PNN formation $[27,55,74]$. In vitro experiments helped unveil which components of PNNs trigger PNN formation. By using a non-neuronal cell line (human embryonic kidney 293T cells) that does not produce a discrete pericellular matrix, it has been shown that the cells are able to produce a pericellular HA coat when overexpressing HAS3. Moreover, HA condenses into a compact matrix when cells also produce both cartilage link protein 1 and aggrecan [43]. In vivo experiments confirmed these findings. In mice lacking cartilage link protein 1 in the CNS, the formation of an organized PNN structure is compromised, although the overall amount of brain CSPGs is unchanged, pointing to a role of cartilage link protein 1 in gathering PNN components [55]. Intriguingly, in the absence of Bral2, PNNs show a substantial reduction of brevican but no changes in aggrecan expression, which indicates that the binding of aggrecan in the PNN does not depend on Bral2 [75]. Based on this and other evidence, it has been proposed that distinct link proteins regulate the micro-organization of PNN via specific interactions with lecticans, e.g., Bral2 with brevican and cartilage link protein 1 with other lecticans [68].

A brain-wide developmental knockout of aggrecan, as well as acute knockout in the adult brain, resulted in impaired aggregation of lecticans and link proteins into PNNs, suggesting that aggrecan is essential for PNN formation and maintenance [76]. Recently, it was shown that phosphacan, the secreted variant of RPTP $\zeta$ (also known as RPTP $\beta$ ) is critical for PNN formation [77]. RPTP $\zeta$ and phosphacan are expressed by glial cells and neurons throughout the developing and adult nervous system [78,79]. In knockout mice without 
RPTP $\zeta$, PNNs lose their typical Wisteria floribunda agglutinin positive (WFA+)/aggrecan+ lattice-like appearance, displaying discontinuous accumulations of WFA/aggrecan. Intriguingly, phosphacan is shown to serve as an anchor of the PNN to the neuronal surface, although its putative receptor is still unknown [77]. Regarding the other CSPGs contained in PNNs, studies in knockout mice show that neurocan and brevican are largely dispensable for PNN formation $[80,81]$. However, PNN formation in quadruple knockout mice lacking neurocan, brevican, tenascin- $\mathrm{R}$ and tenascin-C is significantly delayed in the CA2 in vivo and strongly compromised around primary hippocampal neurons [82-84].

In conclusion, the genetic manipulation of PNN components point to link proteins and aggrecan as key molecules for the assembly and accumulation of a fully organized PNN around neurons, which requires tenascin-R and phosphacan for further stabilization. Functional studies confirm the importance of these molecules for PNN formation. Indeed, in mice lacking cartilage link protein-1 or aggrecan juvenile levels of plasticity persist throughout adulthood (see Section 2.3), and in tenascin-R knockout mice increased axonal plasticity after injury is observed [85].

The formation of PNNs depends on neuronal activity. Rearing animals in darkness from birth prevents PNN formation in the adult visual cortex. Reintroducing dark-reared animals into a normal light/dark cycle enables PNN restoration, which is accompanied by the upregulation of cartilage link protein 1 and aggrecan $[55,86]$. Sensory deprivation in the mouse somatosensory cortex obtained by trimming whiskers from the early postnatal days till adulthood results in decreased PNNs in adult mice [87,88]. Sensory information is also indispensable for PNN development in the spinal cord [89] and the primary auditory cortex [90].

An interesting feature of PNNs during brain development is the change in their morphological organization, from a granular-like pattern in the early postnatal period to a reticular-like pattern later on [88]. Although the functional difference between these patterns is not known, it can be hypothesized that granular-like PNNs may have a weak control on synaptic stability, the maintenance of ion homeostasis, and the repulsion of incoming synapses. Interestingly, WFA+ PNNs also appear as granular structures in prefrontal areas of the adult brain [91], which are highly plastic regions [92]. These less condensed PNNs resemble those of mice lacking tenascin- $R$, which is not detected in the PNNs of the prefrontal cortex [91]. The shift during development from a more disconnected to a more continuous net structure has been shown in detail by Sigal et al. [93] in the mouse primary visual cortex by using super-resolution microscopy. Furthermore, PNNs are granular in short-term neuronal cultures $(<14$ days in vitro) and become more reticular upon maturation [94]. Based on concepts of soft matter physics, it has been proposed that the relative abundance of hyaluronan, CSPGs, link proteins, and tenascin- $R$, as well as their interactions, would determine the degree of matrix compaction, rigidification, and stabilization. Several PNN parameters, such as the size, sulphation, and abundance of CSPGs, the size and number of hyaluronan chains, and/or the abundance of crosslinking molecules, gradually change during CNS maturation, and may thus dictate the structural organization of the PNN [94].

\subsection{PNNs and the Regulation of Critical Periods}

The time of maturation of PNNs coincides with the closure of critical periods in many brain regions. This is apparent in mammalian species, where for instance PNNs are formed at the end of the critical period for ocular dominance plasticity in the visual cortex [86], for the erasure of fear memories in the amygdala [95], for barrel cortex plasticity induced by univibrissa rearing [96], and for leptin-sensitivity of hypothalamic arcuate nucleus neurons that regulate food intake and energy metabolism [34]. Likewise, PNNs mature in song nuclei in birds in parallel with the end of the critical period for sensorimotor vocal learning [97-99]. The idea that PNNs actually contribute to the end of critical periods came when it was shown that the digestion of CS-GAGs by the enzyme chondroitinase ABC $(\mathrm{ChABC})$ restores critical period-like levels of plasticity in the adult CNS (see Box 1 for 
an historical summary of key studies on PNNs). Particularly, the injection of ChABC in the adult visual cortex induces the reactivation of ocular dominance plasticity $[86,100]$. Those studies were followed by many others, which demonstrated increased plasticity in several CNS areas upon the digestion of CS-GAG (reviewed in [101]). However, direct proof was still missing showing that it is the PNNs, rather than the other forms of ECM, that restrict plasticity at the end of the critical period, especially when taking into account that $98 \%$ of CSPGs in the CNS are present in the diffuse ECM and only $2 \%$ are in PNNs [46]. Experiments on mice with defective PNNs, namely mice lacking cartilage link protein-1 or aggrecan, showed that these animals have vestigial PNNs and display persistent ocular dominance plasticity in adulthood, which is indicative of a prolonged critical period [55,76]. PNNs and their CS-GAG chains are thus responsible for dictating the timing of the critical period closure.

Interestingly, PNNs contribute to the end of critical periods for development, not only of sensory systems but also of memory systems, such as those underlying memories of experiences that evoked an emotional reaction (emotional memories). One example of emotional memory is fear conditioning. Animals show a freezing response (which is a sign of fear) to a painful stimulus, such as a foot shock. After repetitively pairing a neutral stimulus, which can be a particular context or a cue (conditioned stimulus), with the foot shock (unconditioned stimulus), animals learn that the neutral stimulus predicts the occurrence of the aversive one and freeze when presented with the neutral stimulus. If an extinction training is then performed, namely, only the neutral stimulus is presented, a decrease in freezing occurs with time. During early postnatal development, the extinction of conditioned fear leads to memory erasure (infantile amnesia), whereas in adult animals, fear conditioning memory is resilient to erasure by extinction (after some time, the fear response can be reinstated by the presentation of the conditioned stimulus). Interestingly, the appearance of PNNs in the amygdala is responsible for the transition from erasureprone to erasure-resistant fear extinction. The digestion of PNNs in the adult amygdala by ChABC reopens a critical period for erasure-like extinction [95], suggesting that PNNs may contribute to the synapse consolidation underlying fear memory retention.

In recent years, our knowledge of a link between PNNs and the control of a critical period for emotional, cognitive, and social behaviors has expanded. Exposure to early life adversity is known to alter neural development in brain regions that are implicated in emotion regulation, cognitive functions, and social interactions, increasing the susceptibility to developing neuropsychiatric disorders in adulthood, including depression, anxiety, drug abuse, and schizophrenia (for reviews, see [102,103]). Interestingly, early-life adverse experiences have been associated with aberrant PNN density and intensity in the adult prefrontal cortex [104], basolateral amygdala [105], and hippocampus [106,107], suggesting that early life stress affects PNN organization throughout the brain. It is also noteworthy that infant rats reared in stressful conditions exhibit longer retention of fear memories than standard-reared rats (for a review, see [7]), where this is accompanied by earlier maturation of GABAergic neurons and PNNs in the amygdala in male individuals [108].

The role of PNNs in hippocampal development is less clear, particularly because the hippocampus is a complex brain region, and its subdivisions might have different time windows for critical periods. A critical period for the development of the hippocampus has been studied in relation to its sensitivity to iron deficiency. As shown in human and animal models, early life iron deficiency results in long-term learning and memory deficits [109-112], as well as abnormal dendritic morphology and a reduced number of PV cells and PNNs in the CA1 [113-115]. If iron is replenished in mice from P21, the behavioral and morphological consequences of early life iron deficiency are normalized, but this does not occur if the iron is replenished from $\mathrm{P} 42$, pointing to a hippocampal critical period for sensitivity to iron deficiency, which ends between P21 and P42 [115]. The work by Umemori et al. [116] showed the increased formation of PNNs in the CA1 and dentate gyrus at P24 when compared to P17, and suggested that at P24, the critical periods of those brain regions are closing. Interestingly, PNNs in the CA1 and dentate gyrus at P24 are decreased 
following perinatal exposure to the selective serotonin reuptake inhibitor fluoxetine [116], which is an anti-depressant that is approved for use during pregnancy and lactation that can, however, represent chemical stress for the developing fetus. Adult rats that received fluoxetine perinatally exhibited depression-like behaviors [117]. Overall, delayed maturation of PNNs in the CA1 might be responsible for long-lasting cognitive/psychiatric impairments. The hippocampal area CA2 is required for the formation of social memories, and particularly social recognition memory, namely the ability to recognize a novel or familiar conspecific [118]. The CA2 contains a population of large pyramidal neurons [119], which are surrounded by prominent PNNs. Similar to other brain regions, in the CA2, PNN formation is experience-dependent [32]. The digestion of adult PNNs results in the enhanced synaptic potentiation of excitatory synapses on CA2 neurons, raising the possibility that PNNs control a critical period for CA2 synaptic plasticity and related behavior [32].

How do PNNs restrict plasticity? CSPGs can bind effector molecules, exposing them to their receptors, or can mediate the uptake of regulatory molecules by neurons. Two molecules have recently been discovered as CS-GAG-binding molecules, which represent examples of either mechanism of action: Sema3A and Otx2 (Figure 1C). Best known for its role as a chemorepulsive axon guidance protein during nervous system development, Sema3A is also abundantly expressed by neurons throughout the adult CNS [120], where it is localized to the CSPGs in PNNs [121]. It can bind with high affinity to CS-E motifs [63], although recent evidence points to a strong affinity of Sema3A for nonsulfated GalNAc residues of CS chains [122] and CS-A [123]. In the visual cortex, Sema3A accumulates in PNNs in coincidence with the closure of the critical period, where this accumulation is experience dependent. Interestingly, in adult rats, dampening Sema3A signaling by overexpressing an inactive Sema3A receptor restores juvenile levels of ocular dominance plasticity [124]. These data indicate that Sema3A contributes to PNN-mediated restriction of plasticity at the end of a critical period. The exact mechanism of how Sema3A exerts its effects is not known. During development, Sema3A requires a receptor complex that is composed of neuropilin-1 and plexinAs to achieve repulsive guidance signaling. Neuropilin-1 binds to Sema3A and plexin and is essential for the stabilization of the Sema3A-plexin interaction [125]. Sema3A receptors plexinA1 and lexinA4 are also expressed in adult neurons [126]. In the cerebellar nuclei, where strong perineuronal Sema3A is present, both nuclear neurons and their pre-synaptic afferents, the Purkinje cell axons, express the Sema3A receptor component plexinA1 and $4[126,127]$. Neuropilin-1 is strongly expressed in the molecular layer of the dentate gyrus, where entorhinal stellate neurons project their axons [128]. PlexinAs are also found on the membrane of PV neurons [121]. It can be hypothesized that by interacting with its receptors on the plasma membrane of a postsynaptic neuron, Sema3A captured in PNNs may have an effect on the neuron itself. For instance, Sema3A signaling may cause cytoskeletal changes, which may affect the distribution of postsynaptic receptors, and thus, neuron plasticity and/or connectivity. Another mechanism of action may involve Sema3A signaling in presynaptic terminals. Sema3A that gradually accumulates in PNN may repel incoming Sema3A-sensitive axons, thus preventing them from forming synapses on PNN-bearing neurons. During adulthood, Sema3A in PNNs could stabilize existing synapses on the postsynaptic neuron. Finally, because it has been shown that Sema3A is able to rigidify CS-E-based matrices, it may cross-link PNN-GAGs, stabilizing the PNN structure [129].

The cellular source of the Sema3A protein in PNN is not entirely clear. Sema3A mRNA is detected in many neurons throughout the CNS [120]. Sema3A-positive PNNs can be found around both neurons that express Sema3A mRNA and neurons that do not. In cultured neurons, Sema3A is actively transported in vesicles through the axon and dendrites, and in axons, it is transported in an anterograde direction in an activitydependent manner [130]. Sema3A protein might thus be produced by neurons, transported to their terminals, and then deposited in the PNN around postsynaptic neurons. In addition, Sema3A is expressed by choroid plexus cells (our unpublished observations) and meningeal 
cells [131]. Sema3A may be released by cells of the choroid plexus or meninges in the cerebrospinal fluid and travel through the brain parenchyma to bind to PNNs.

Otx2 is a homeoprotein transcription factor that controls the regionalization of the vertebrate brain during embryonic development. Like many homeobox proteins, it can be transferred between cells. During cortical postnatal development, Otx2 is preferentially internalized by $\mathrm{PV}$ cells and promotes their maturation, consequently regulating the onset of a critical period [17,132]. Interestingly, CS-GAG of the PNN, and particularly CS-D and CS-E, participate in the specific recognition of Otx2 before its internalization, interacting with a short motif containing an arginine-lysine (RK) doublet within the Otx2 sequence [60]. Moreover, Otx2 is required for PNN assembly during the critical period. When the amount of Otx2 is genetically reduced or the GAG-recognition motif of Otx2 is mutated, mice show a delay in the maturation of the PNNs and the critical period onset across several cortical areas $[17,132]$. The infusion of Otx 2 in the visual cortex before the onset of the critical period or in animals reared in darkness accelerates PNN formation, as well as both the onset and the end of the critical period [17]. In addition, injection of the RK peptide in the adult mouse visual cortex induces a reduction of Otx2 accumulation in PV+ neurons, a decrease in PV and WFA staining, and an increase in visual cortex plasticity [60]. Similar results are obtained when Otx2 transfer in PV cells is blocked by infusing a synthetic CS-E analog in the adult cortex [62]. Accordingly, blocking Otx2 internalization into PNN-bearing neurons in the adult visual cortex leads to a reduction in WFA+ PNNs and a restoration of juvenile levels of plasticity [133]. In addition, mice in which the binding of Otx2 to PNN was genetically reduced show increased plasticity in adult cortical areas, in parallel with the reduced PNN accumulation [132]. In the adult brain, one of the main sources of cortical Otx2 is the choroid plexus [134,135]. Knocking-down Otx2 specifically in the choroid plexus decreases Otx2 cortical content and results in reduced PV expression and PNN assembly, as well as increased plasticity. Therefore, Otx2 is a crucial molecule for maintaining the PNNs in a mature state and restricting adult plasticity in sensory systems. The mechanisms through which Otx2 regulates PNN maturation and maintenance are largely unknown. Recently, an association between Otx2 and aggrecan mRNA has been found, suggesting that aggrecan expression may be post-transcriptionally promoted by Otx2 [136]. Moreover, Gadd45b/g have been identified as direct targets of Otx2. The Gadd45 family has been implicated in epigenetic gene activation [137-139], which can impact plasticity $[140,141]$. Gadd45b/g cortical expression increases during the cortical critical period and declines as plasticity is turned off, and is apparent in cells that internalize Otx2. Gadd45b induces the upregulation of a number of genes that are associated with plasticity, including Arc, Fos, Egr2, and Egr4, possibly by triggering changes in the DNA methylation of these genes. Therefore, in adults, Otx2 may induce the downregulation of plasticity genes by suppressing the expression of Gadd45b [142].

The role of Otx2 in the maturation and plasticity of other systems, such as those regulating emotions or learning and memory, is still unknown. Because Otx2 may potentially reach PNN-bearing neurons in the whole brain via the cerebrospinal fluid, it may contribute to the orchestration of critical periods underlying different behaviors.

Several other growth factors bind with high affinity to CS-GAGs. These molecules include nerve growth factor, BDNF, neurotrophin 3, midkine, pleiotrophin, hepatocyte growth factor, and fibroblast growth factor $2[143,144]$. However, it is not known whether they interact specifically with CS-GAGs in PNNs. CSPGs also associate with cell adhesion molecules, such as the neural cell adhesion molecule (NCAM), the neuron-glia cell adhesion molecule (NG-CAM), and contactin [52,145]. Interestingly, the neurocan interaction with NCAM impairs the association between NCAM and ephrin type-A receptor 3 , and thus, the activation of ephrin type-A receptor 3 signaling, which is responsible for the repulsion of GABAergic synapses on pyramidal cortical neurons. This points to a role for the neurocan-NCAM association in synapse stabilization [146]. Furthermore, the enzymatic digestion of CSPGs in the general perisynaptic matrix affects dendritic spine 
motility through an integrin-related mechanism $[147,148]$, where integrins can inactivate CSPGs [149]. However, this mechanism has not been explored for PNN-CSPGs.

Interestingly, the PNN component brevican directly regulates the localization of potassium channels and the levels of synaptic AMPA receptors, as well as the maturation of excitatory inputs into PV cells. In the absence of brevican, GluA1 subunits of AMPA receptors fail to cluster in postsynaptic densities, where this may underlie the loss of excitatory synaptic contacts onto PV+ interneurons [150]. Similarly, hyaluronan digestion increases the movement of AMPA receptors between synaptic and extrasynaptic domains, allowing for a faster replacement of desensitized receptors by naïve functional ones, thus impacting short-term synaptic plasticity [151]. For a detailed review of the effects of the ECM on synaptic properties see $[19,152]$.

CSPGs can also exert their effects through their binding to specific receptors. CSPG receptors have been discovered in the context of CNS injury, where CSPGs are upregulated in the glial scar and inhibit axon regeneration. These receptors include receptor-type tyrosine-protein phosphatase S (PTPRS; also known as PTP $)$ ), leukocyte common antigenrelated phosphatase (LAR) [153,154], and Nogo receptor-1 and -3 [155]. However, a role for these receptors in PNN functions has yet to be elucidated.

Box 1. An historical view of the PNN.

PNNs were first observed in 1898 by Camillo Golgi after using a slightly modified version of the silver impregnation technique developed by him. They were described as a "delicate covering around nerve cells, made of a substance that is clearly distinct from the cell body structure, and that appears like a reticular structure, a continuous envelop, or made of contiguous little tiles; mainly looking like a chain mail armor, it enwraps the cell body as well as protoplasmic prolongments up to second and third order arborizations" [156]. A few years later Ramón y Cajal argued that PNNs were artefacts deriving from the coagulation of substances dissolved in pericellular fluids [157], thus discouraging further research in the field for many decades. In the 1960s periodic-acid-Schiff (PAS) positive components have been observed around neurons [158]. PAS staining is used to reveal polysaccharides [159]; however, at that time the similarities were not seen between the PAS-positive material and Golgi's finding. In the 1980s and 1990s, thanks to advances in the field of histochemistry PNNs were undeniably visualized, and interest in these structures was sparked again. The use of plant lectins, such as Wisteria floribunda agglutinin (WFA), Vicia villosa agglutinin and soy bean agglutinin, all capable of binding to $\mathrm{N}$-acetylgalactosamine residues $[160,161]$; the use of colloidal iron hydroxide, for detection of negatively or positively charged components [162]; and the use of monoclonal and polyclonal antibodies to CSPGs [36] were all instrumental to further our understanding of the PNN structure. WFA is still widely used as a general marker for PNN-CS, binding non-sulfated GalNAc residues [122]. Immunohistochemical and in situ hybridization studies provided more insight into the molecular composition of PNNs and the cellular origin of PNN components $[27,29,49]$. At the beginning of the 21st century the seminal work of J. Fawcett (University of Cambridge, UK), T. Pizzorusso and L. Maffei (CNR, Pisa, Italy) implicated the PNNs as crucial regulators of plasticity [86]. Since then, studies on PNNs have proliferated at a fast pace (out of 642 total articles, 562 were published since 2002-Pubmed search), unveiling new PNN components, properties and functions. For an historical timeline of research on PNNs, see Figure 2. 


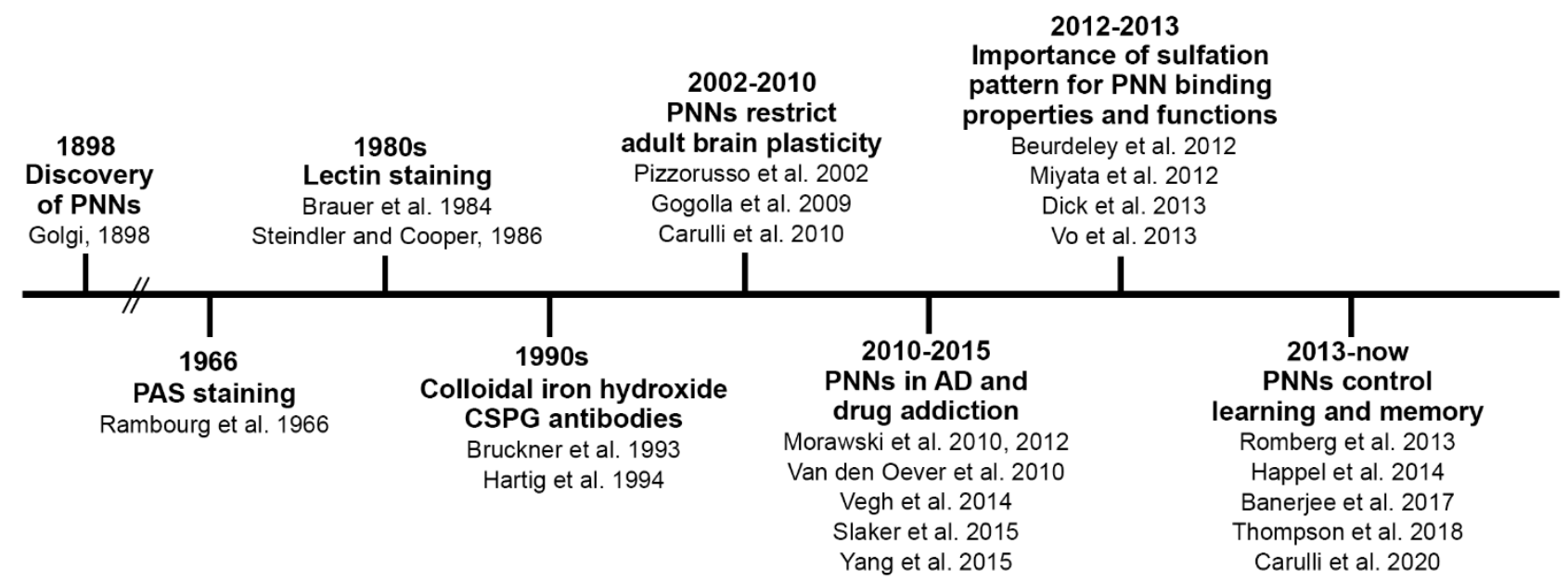

Figure 2. Timeline of key PNN-related discoveries. The timeline shows some of the critical contributions to the PNN field, from the first papers in which PNNs were visualized to the first studies elucidating PNN molecular composition and PNNs' role in plasticity and disease. AD: Alzheimer's disease, PAS: periodic acid-Schiff.

\section{PNNs and the Mature Brain}

\subsection{PNN Dynamics and Brain Physiology}

As we discussed in the previous section, the maturation of PNNs dictates the end of the critical period for plasticity in a number of brain regions, reducing the ability of new experiences to leave a permanent trace in the brain and maximizing the storage of previously acquired information. However, PNNs must not be viewed as static structures (Figure 3). There are several examples of changes in PNN structure and number in concomitance with episodes of neuronal plasticity in the adult brain. For instance, when adult mice or rats are exposed to enriched environmental stimulation that provides enhanced social stimuli, sensory inputs, and motor activity, ocular dominance plasticity is restored, learning performance is improved, hippocampal neurogenesis is increased, and neuritic rearrangements occur in several brain regions [163-166]. Intriguingly, PNNs throughout the brain are reduced in animals exposed to enriched environmental stimulation [150,163,164,167]. The effects of an enriched environment on PNN expression in the spinal cord are opposite to those observed in the brain, as it causes an increase in PNN thickness [167]. Therefore, enhanced levels of activity, while decreasing PNNs to boost plasticity in the brain, may increase PNNs in the spinal cord to make spinal cord connections more stable and thus ensure efficient output.
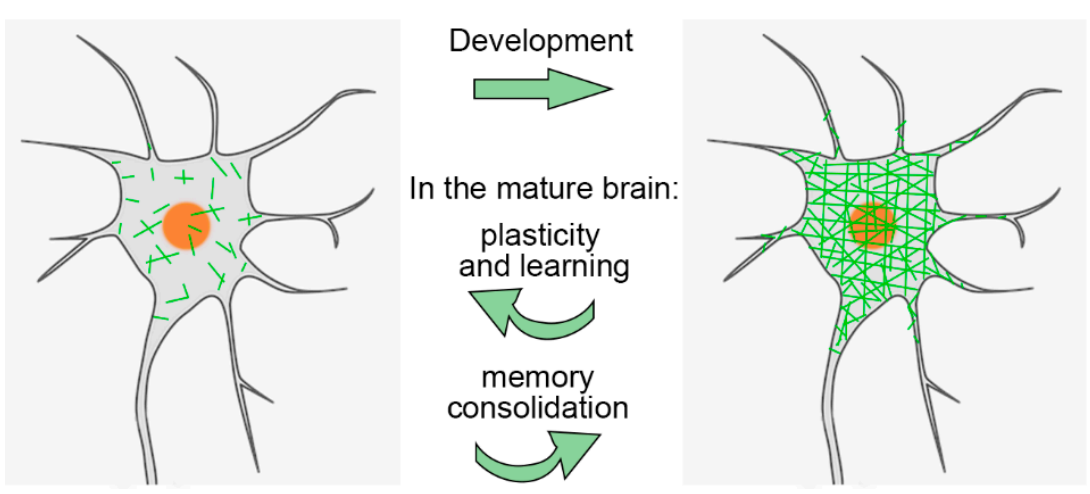

Figure 3. Dynamics of PNNs. The scheme shows that PNN components accumulate and gather around the cell body, proximal dendrites and axon initial segment of a neuron during postnatal development. However, once formed, the PNN is not a static structure. In the adult brain PNNs are reduced, for instance, during learning, and restored when the learning phase is terminated and memories are consolidated. 
Another example of PNN dynamics is observed in the hypothalamus. Strong attenuation of PNN-associated phosphacan is observed around vasopressin+ magnocellular neurons of the rat supraoptic neurons in response to salt loading [168], which triggers dramatic structural plasticity in that area, including neuron hypertrophy, the juxtaposition of somata and dendrites, the retraction of astrocytic processes, and synaptic sprouting [169]. Upon the cessation of salt loading stimulation, phosphacan expression is restored to basal values and structural changes are reversed. Again, in this system, there is a tight correlation between PNN expression and the levels of plasticity.

There is a strong link between serotonin levels and plasticity. Increasing serotonin levels via fluoxetine administration results in enhanced plasticity in the adult visual cortex, hippocampus, and medial prefrontal cortex. This is associated with reduced intracortical inhibition and PNNs [170-172]. When the GABA tone is pharmacologically reduced in the visual cortex of adult mice, ocular dominance plasticity is enhanced and the expression of PNNs is diminished, indicating that a mature level of cortical inhibition limits adult cortical plasticity [173].

Interestingly, very rapid changes in PNN CS-GAGs (i.e., within $24 \mathrm{~h}$ ) occur in mouse brain regions involved in emotional memory, where these changes follow circadian rhythms. The number of WFA+ neurons generally peaks at zeitgeber time 20, when mice are awake, and is lowest at zeitgeber time 6-8, when mice sleep [174]. These data suggest that PNN composition may be regulated in a circadian manner to allow for circadian synaptic plasticity, with PNN decrease during sleep favoring the synaptic refinement that is required for memory consolidation [175]. For instance, during rapid eye movement (REM) sleep, memory representations are transferred from short-term storage sites, such as the hippocampus, into long-term storage sites in neocortical areas, where they are strengthened, and shortterm storage memories are removed via synaptic pruning [176]. Indeed, sleep deprivation, which is known to prevent synaptic modification that occurs in the hippocampus during sleep $[177,178]$, precludes a WFA-PNN decrease and leads to an increase in fear memory extinction [174]. Alternatively, since PNNs are known to be important for protecting neurons from oxidative stress [179-181], rhythms in PNN composition may reflect periods of reduced oxidative stress during sleep. Indeed, following sleep deprivation, increased oxidative stress in PV+ neurons is accompanied by an increase in the WFA labeling of PNNs [182].

Dynamic PNN rearrangements are also reported after an injury to the CNS. For instance, following unilateral damage to the labyrinth, which causes severe oculomotor and postural symptoms, PNNs in the vestibular nuclei are initially reduced. Subsequently, vestibular deficits usually resolve due to a process known as vestibular compensation, where PNNs are reinstated, suggesting that a PNN decrease may allow for synaptic remodeling to occur during vestibular compensation [183]. Moreover, PNNs are modulated during injury-induced neuritic remodeling, such as in cortical areas affected by stroke [184], in the denervated cerebellum [185], or after a spinal cord injury [186].

We can conclude that PNN expression can be altered in the adult CNS in conditions in which plasticity is to be modulated. This is also the case during learning and memory processes, which are discussed in the next section.

\subsection{PNNs during Learning and Memory}

Remarkable changes in PNNs occur during the formation and consolidation of memories, which are typical plasticity-based processes. The acquisition of auditory fear memory is associated with an increase in PNNs in the hippocampus, auditory cortices, and anterior cingulate cortex $[187,188]$. The formation of cerebellum-dependent motor-associative memories is accompanied by a reduction in PNNs in cerebellar nuclei, followed by a restoration of the PNNs when memories are consolidated [189]. Similarly, brevican in PNNs surrounding hippocampal PV neurons is decreased during learning in the Morris water maze and returns to baseline levels upon learning accomplishment [150]. An increasing amount of evidence highlights changes in PNNs during the consumption of drugs of 
abuse (cocaine, heroin, nicotine, and alcohol) and drug-associated memories. Modulation of the expression of PNN components is shown to depend on the type of drug, the duration of drug exposure and withdrawal, and the brain region studied (for a review, see [190]). For example, in the cerebellum, which is activated during exposure to drug-associated cues, possibly to mediate the unconscious prediction of drug availability [191], WFA labeling of PNNs is altered following cocaine administration [192-194]. Moreover, the formation of cocaine-related preference memories is accompanied by the increased expression of PNN-CSPGs around cerebellar Golgi neurons [195]. In the medial prefrontal cortex, which is involved in drug-seeking, reinforcement-learning, and goal-directed behavior, long-term abstinence from heroin self-administration is associated with a decrease in the protein levels of several PNN constituents at the synapses, suggesting that changes in the ECM upon the cessation of heroin self-administration may influence the relapse to drug seeking [196]. Acute cocaine exposure decreases WFA labeling in PNNs of the prefrontal cortex, whereas repeated cocaine administration increases it [197]. Binge-like ethanol consumption in mice induces an increased accumulation of CSPGs in PNNs around insular cortex neurons [198]. Since drug abuse induces an increase in reactive oxygen species in the brain [199], it can be speculated that PNN changes following drug consumption are a consequence of oxidative stress. Indeed, although PNNs are important for protecting neurons from oxidative stress [179-181], they are themselves susceptible to it [180].

PNN modulation is not simply an epiphenomenon of learning and memory processes, a causal link also exists between them (Figure 3). For instance, the manipulation of PNNs in the hippocampus and cortex demonstrates that PNNs are crucial for consolidating and/or maintaining long-term fear memories. Indeed, hyaluronidase injection in the hippocampus before fear conditioning results in impaired contextual fear memory [200]. Similarly, following intrahippocampal infusions of $\mathrm{ChABC}$ and hyaluronidase prior to fear conditioning training, rats show a profound impairment in contextual fear memory, but no change in memory acquisition [201]. The injection of ChABC in the auditory cortex or hippocampus of mice abolishes fear memory after fear conditioning, with no impact on the fear learning process $[187,188]$. The digestion of PNNs in the secondary visual cortex impairs the storage of remote visual fear memories [202]. Following increased PNN expression in the hippocampus by overexpressing cartilage link protein 1, the recall of remote fear memories is significantly enhanced [188]. PNNs are also implicated in the consolidation of motor-associative memories, as the disruption of PNNs in the cerebellar nuclei by ChABC impairs memory retention in the eyeblink conditioning paradigm [189]. In addition, PNNs are involved in the consolidation of memory of the environments in which drugs are used, which is a crucial factor in triggering relapse to drug reuse. The role of PNNs in drug addiction is further discussed in Section 4.2. As mentioned in Section 2.3, the degradation of PNNs in the amygdala makes subsequently acquired fear memories susceptible to erasure by extinction, pointing to a key role of PNNs in protecting fear memories from erasure [95]. PNN removal in the perirhinal cortex or in the CA3, which are important for object recognition memory, results instead in prolonged memory [76,165,203].

Only a few studies addressed the role of PNN in learning. Removing PNNs in the auditory cortex by using hyaluronidase leads to increased reversal learning, i.e., the ability to relearn a task that requires behavioral flexibility [47]. ChABC administration in the cerebellar nuclei results in faster and better motor-associative learning [189,204]. In addition, the removal of PNNs in the hippocampus of mice showing impaired spatial learning due to defective neuropeptide $Y$ signaling reverses learning deficits [205]. Taken together, these findings are consistent with the idea that PNN removal promotes plasticity.

Overall, PNNs appear to have a dual role: on the one hand, they can hamper new learning by restricting plasticity, while on the other hand, they can protect memories by stabilizing synaptic connections. Therefore, PNNs associated with specific populations of neurons may be a potential target for therapeutic interventions aiming at either increasing learning processes, potentiating adaptive memory, or erasing traumatic memories. 


\subsection{Role of Metalloproteinases}

The mechanisms underlying PNN modifications are far from clear. The decrease in PNNs that occurs during plasticity-associated conditions may involve matrix-degrading enzymes. Many matrix metalloproteinases (MMPs) are released by neurons in response to activity or during plasticity processes, including learning/memory (for a review, see [206,207]). Many PNN components are known to be digested by MMPs and ADAMTSs (a disintegrin and metalloproteinase with thrombospondin motifs) (for a review, see [208]). Indeed, following an enriched environment, increases in MMP2 and -9 are observed in cerebellar nuclei neurons that have low PNN expressions [164], and no decrease in cerebellar PNNs is found in knockout mice for MMP9 [209]. The induction of ocular dominance plasticity in adult mice by light reintroduction after dark exposure is associated with PNN degradation, which is mediated by MMP9 [210]. MMP9 is also released in rodents during fear conditioning [211]. Two other MMPs, namely, MMP3 and MMP13, are upregulated in PV neurons after seizures [212]. Metalloproteinases belonging to the ADAMTS family, namely, ADAMTS1 and ADAMTS4, degraded brevican in a rat model of epilepsy [213]. In addition, PV interneurons enwrapped in PNNs specifically expressed Adamts8 and Adamts15 [214], suggesting that PNN-bearing neurons themselves are able to change their surrounding matrix. Matrix metalloproteinases produced by microglia cells are also involved in ECM/PNN remodeling. For example, cathepsis-S is a microglia-derived matrix protease, which shows a diurnal rhythmic expression that is opposite to PNN rhythms. The application of cathepsin-S to mouse brain sections eliminates WFA-PNN labeling, suggesting that it may be crucially involved in circadian PNN modulation [174]. Microglia cells are also able to engulf ECM molecules and clear them from the perisynaptic milieu, where this process may contribute to experience-dependent synapse remodeling and memory consolidation [215]. Moreover, microglial dysfunction in the hippocampus results in increased ECM expression and a reduction in dendritic spines [216]. In line with this evidence, depletion of microglia leads to a substantially increased accumulation of PNNs in the cortex and prevents the PNN loss that is found in the cortex in a model of Huntington's disease [217]. Thus, microglial cells might be crucial regulators of PNN maintenance, where they are actively involved in the degradation of the ECM to allow for synaptic plasticity.

Although metalloproteinase activity may account for the rapid local changes in ECM molecules that occur around synapses during plasticity-related events, changes in the synthesis of PNN components and in CS-GAG sulfation patterns may also contribute to PNN modulation in the adult brain, as it occurs during development and aging $[51,56,164,187]$.

\subsection{PNNs during Aging}

Brain aging is characterized by a decline in sensory, motor, and cognitive functions, and is associated with a progressive reduction in neural plasticity. Hence, an increase in PNN expression during aging is expected. Although contrasting evidence has been presented, there is a general agreement that this is indeed the case. In middle-aged mice (12 months old), the density of WFA+ PNNs in the somatosensory and visual cortex is increased in comparison to that in young adults ( 3 months old), particularly around GABAnegative neurons [218]. In another study, the PNN-WFA intensity in the dorsal part of the hippocampus is reduced in the CA1 region, whereas it is not changed in the CA3 region, and is increased in the dentate gyrus when compared to 2-month-old mice. No significant aging-related changes in PNN-WFA intensity have been detected in the ventral hippocampus [31]. However, in older mice (18 months of age), a substantial increase in WFA staining in both PNNs and the diffuse ECM is detected in the whole hippocampus when compared to young animals ( 3 months of age), and strong age-dependent upregulation of ECM proteins, such as cartilage link protein 1, brevican, and neurocan, in hippocampal synaptosomes is found [219]. In primary sensory cortices, but not in associative cortices, the number of neurons surrounded by a PNN is increased in 12-month-old mice when compared to 2-month-old mice [220]. A substantial increase in perineuronal aggrecan staining is reported in the pre-frontal cortex and the hippocampal CA3 area of very old 
rats (24 months old) [221]. In the striatum, CSPGs accumulate in PNNs and the diffuse ECM in an aging-dependent manner, and ChABC administration in aged mice significantly improves age-related motor deficits [222].

An age-dependent increase in perineuronal/perisynaptic ECM levels may well contribute to cognitive and motor impairments during aging by reducing molecular and cellular signaling mechanisms that are normally required for plasticity to occur.

When studying the expression levels of CS-GAGs, Foscarin et al. [56] found that the total amount of GAGs isolated from the general diffuse brain matrix and the PNN matrix of rats are stable with age. The amounts of C4S and C6S in the diffuse ECM also remain stable in the aged brain (12 and 18 months of age) when compared to young brains, but $\mathrm{C} 6 \mathrm{~S}$ in the PNN fraction are strongly reduced, leading to an increase in the C4S/C6S ratio. In addition, the late loss of $\mathrm{C} 6 \mathrm{~S}$ in the aged brain makes PNNs more inhibitory to neurite growth than in the young brain, as the 18-month PNN-GAGs are more inhibitory than 3 -month PNN-GAGs in vitro [56]. These data point to important changes in PNN-GAG sulfation in aged brains, which may be responsible for the plasticity decline and memory impairments that are typically found in aged individuals.

\section{PNNs and Memory-Related Diseases}

In the last decade, several studies focused on the relationship between PNNs and various brain diseases, including schizophrenia, epilepsy, depression, multiple sclerosis, and Huntington's disease [217,223-226]. Here, we address PNN changes and their roles in two widespread memory-related diseases, namely Alzheimer's disease (AD), in which memory formation is compromised, and drug addiction, in which maladaptive memories are present.

\subsection{PNNs in Alzheimer's Disease}

$\mathrm{AD}$ is a progressive neurodegenerative disease that affects the neocortex and hippocampus and is characterized by impaired learning and retrieval of memories. Two hallmarks of AD are extraneuronal deposition of the amyloid-beta protein in the form of plaques and intraneuronal aggregation of the microtubule-associated protein tau in the form of filaments [227,228]. Some studies document a partial loss of CS-GAGs/CSPGs in the PNNs of patients and mouse models of AD, particularly in the cingulate, frontal, temporal, and entorhinal cortexes [224,229,230] and middle frontal gyrus [231] in humans, and in the hippocampus CA1, CA2, and CA3 [232], subiculum, and visual cortex [231] in mice. However, other studies report no alteration of PNNs in the brains of AD patients or mice in the human insular cortex and subcortical regions [233]; human primary sensory, secondary, and associative areas of the temporal and occipital lobe [234]; mouse parietal cortex [233]. A recent study pointed to an intriguing role of microglia activation, triggered by amyloid plaques, in mediating extensive PNN loss in a mouse model of AD [231]. While there are no studies reporting a PNN increase in human AD brains, mice characterized by amyloid-beta plaque production (APP/PS1 mice) show increased WFA labeling around hippocampal PV neurons and the upregulation of several ECM proteins in hippocampal synaptosome preparations at early stages (3 months of age), when amyloid-beta plaques are not yet observed, but when contextual fear memory is impaired and long-term potentiation (LTP) is reduced. These physiological and behavioral deficits are reversed when the ECM/PNNs are removed by ChABC, indicating that perisynaptic ECM accumulation may contribute to early memory and plasticity impairments in AD [235]. Interestingly, PNNs may protect neurons and synapses from amyloid toxicity, as shown in vitro [236], and from tau pathology [233,237]. Direct evidence for a role of PNN in neuroprotection is shown in the study by Suttkus et al. [238]. When exogenous tau protein is added to brain organotypic cultures, it is mainly internalized in neurons without a PNN. However, if the PNN is disrupted due to the lack of aggrecan, link protein 1, or tenascin-R, tau becomes internalized in PNN neurons as well. Membrane-associated heparan sulfate proteoglycans have been shown to induce the internalization of tau aggregates [239]. PNNs may bind 
tau aggregates (possibly through the large polyanionic molecule aggrecan), therefore inhibiting their interaction with the heparan sulfate proteoglycans and, as a consequence, their internalization.

In order to overcome the progressive loss of functional connections due to neurodegeneration in $\mathrm{AD}$, new connections may help bypass nonfunctional neurons, leading to functional improvements. To help form new connections, the degradation of PNNs may be beneficial. In the study by Yang et al. [240], the digestion of PNNs in the perirhinal cortex of AD mice with neurodegenerative tauopathy, in which object memory decays rapidly, results in restoration of normal synaptic transmission and behavioral amelioration. As highlighted above (see Section 2.2), the sulfation pattern of CS-GAGs affects CSPG binding properties and function, with 4-sulfated CS-GAGs being inhibitory to neurite growth. Interestingly, in tauopathy mice, the administration of antibodies blocking 4-sulfated CS-GAGs in the perirhinal cortex is sufficient to restore object memory [123].

Overall, there is some discrepancy between studies investigating PNN changes in AD human tissue, as well as in mouse models, with some studies reporting no changes and others reporting a PNN reduction. These differences in mice may depend on the mouse genetic background, and in humans, on the disease stage, the brain area investigated, the age of the patient, and technical issues. Moreover, AD mouse models do not always match with the human pathology, as PNN expression is increased in some mouse models of AD, whereas in human AD brains, PNNs are mostly decreased or unchanged. Given the important role of sulfation patterns in PNN functions, it would be interesting to address whether PNN sulfation in brain regions affected by AD is different from that of healthy subjects. PNN sulfation pattern can be a potential therapeutic target for improving AD symptoms.

PNNs are shown to have a neuroprotective role against tau pathology. However, beneficial effects on memory were obtained by acute PNN disruption in tauopathy mice [240]. Further studies are needed to elucidate the synaptic/anatomical changes underlying memory restoration, as well as long-term effects, following PNN manipulation in AD mice. Moreover, in view of developing therapeutic strategies, the dual role of PNNs in neuroprotection and the restriction of plasticity should be taken into account.

\subsection{PNNs and Drug Addiction}

Drug addiction is considered a chronic relapsing disorder, in which craving and relapse to drug seeking occur even after prolonged abstinence [241]. This is because addiction involves many of the same brain circuits that govern learning and memory. Exposure to environmental stimuli that have previously been associated with the effects of selfadministered drugs is often a major contributor to relapse, as it evokes memories of the effects of the drug [241,242]. Given the role of PNNs in learning and memory processes, including associative memories, it is not surprising that PNNs are not only altered following drug consumption or during addiction (see above) but also play an active role in the consolidation of addiction memories [190,243]. Memories of drug-associated environmental cues are assessed using the conditioned place preference test, in which animals learn to associate the environment in which they received the drug with the internal positive state achieved while on the drug, and thus spend more time in the drug-paired compartment, even in the absence of the drug. In rats that received a ChABC injection in the prelimbic cortex or the anterior dorsal region of the lateral hypothalamus before conditioning, the development of a cocaine-conditioned place preference is attenuated, indicating that PNNs in those brain regions are important for memories of drug-environment associations [244,245]. Moreover, PNNs in the anterior dorsal region of the lateral hypothalamus are instrumental for the expression of the cue-induced reinstatement of cocaine-seeking behavior [246]. Interestingly, when $\mathrm{ChABC}$ is injected into the prefrontal cortex after extinction, but before the reactivation of the cocaine memory, the preference for the cocaine-paired chamber is attenuated, suggesting that PNNs are also important for memory reconsolidation [244]. In accordance with the results shown by Gogolla et al. [95], in which the reinstatement 
of a fear memory is reduced after ChABC injection in the amygdala, PNN digestion in the amygdala enables extinction training to erase drug memories, attenuating the reinstatement of morphine-induced and cocaine-induced conditioned-place preference [247]. Together, these observations highlight a crucial role of PNNs in memory of drug-associated environments and suggest that targeting PNNs might be a therapeutic strategy to suppress these maladaptive memories and prevent relapse to drug use.

\section{Conclusions}

Although at the time of their first detection, PNNs did not receive much attention, being considered as mere staining artifacts, later they were recognized as an integral part of the brain maturation process, especially with the unexpected discovery of a link between PNNs and brain plasticity [86]. In the adult brain, PNNs turned out to be more dynamic than initially thought, and they took center stage in what is considered to be one of the great mysteries of neuroscience, namely, how memories are encoded in the brain $[95,248,249]$.

To get a better understanding of PNN dynamics, however, the production of tools allowing for live PNN imaging would be required. This way, temporal changes in the structure and expression of PNNs in vivo, for instance, during learning and memory, might be unveiled. Furthermore, developing molecular tools (vectors, antibodies, peptides, antagonists, etc.) to specifically interfere with PNN components would be beneficial to further our understanding of PNN functions and, in view of designing therapeutic tools, to improve certain CNS conditions. Most studies have used ChABC to remove PNNGAG chains and increase CNS plasticity. However, in the context of human therapy, this approach is not feasible, as multiple injections of the enzyme would be needed to target large volumes of the human brain and to ensure a long-term supply of it. The delivery of ChABC via viral vectors, which can ensure a cell-type-specific and continuous delivery of the enzyme, may be a promising strategy to overcome those issues [189,250-252]. The recent development of an immune-evasive and time-regulatable ChABC gene therapy system [253] is a further step in this direction. It has to be noted, though, that ChABC treatment affects PNNs, as well as diffuse and membrane-bound CS-GAGs, and is therefore not ideal when there is the need to specifically target PNNs. Even when targeting PNNCSPGs, ChABC can be considered a crude intervention, as it affects all CS-GAGs and, in turn, CSPG-binding partners, which may play distinct roles in the control of plasticity. Therefore, targeting specific components of the PNN seems a better approach. Potentially interesting candidates in this respect are Sema3A and Otx2. Further studies are needed to unravel their precise role in physiological conditions, such as during learning and memory or the aging process, as well as in pathological conditions. In addition, given the crucial role played by specific sulfated CS-GAGs in PNN binding properties and the regulation of plasticity, memory, and aging, targeting the sulfation pattern of CS-GAGs may be another strategy to delicately manipulate PNNs.

Funding: The work was supported by the Netherlands Organization for Scientific Research (grant number: 2019/ENW/00772598).

Conflicts of Interest: The authors declare no conflict of interest. The funders had no role in the design of the study; in the collection, analyses, or interpretation of data; in the writing of the manuscript, or in the decision to publish the results.

\section{References}

1. Reh, R.K.; Dias, B.G.; Nelson, C.A., 3rd; Kaufer, D.; Werker, J.F.; Kolb, B.; Levine, J.D.; Hensch, T.K. Critical period regulation acrossmultiple timescales. Proc. Natl. Acad. Sci. USA 2020, 117, 23242-23251. [CrossRef] [PubMed]

2. Hubel, D.H.; Wiesel, T.N. Receptive fields, binocular interaction and functional architecture in the cat's visual cortex. J. Physiol. 1962, 160, 106-154. [CrossRef]

3. Hubel, D.H.; Wiesel, T.N. Binocular interaction in striate cortex of kittens reared with artificial squint. J. Neurophysiol. 1965, 28, 1041-1059. [CrossRef] [PubMed]

4. Fifková, E. Changes in the visual cortex of rats after unilateral deprivation. Nature 1968, 220, 379-381. [CrossRef] [PubMed] 
5. Antonini, A.; Stryker, M.P. Plasticity of geniculocortical afferents following brief or prolonged monocular occlusion in the cat. J. Comp. Neurol. 1996, 369, 64-82. [CrossRef]

6. Dews, P.B.; Wiesel, T.N. Consequences of monocular deprivation on visual behaviour in kittens. J. Physiol. 1970, 206, 437-455. [CrossRef]

7. Callaghan, B.L.; Graham, B.M.; Li, S.; Richardson, R. From resilience to vulnerability: Mechanistic insights into the effects of stress on transitions in critical period plasticity. Front. Psychiatry 2013, 4, 90. [CrossRef]

8. Southwell, D.G.; Froemke, R.C.; Alvarez-Buylla, A.; Gandhi, S.P. Cortical Plasticity Induced by Inhibitory Neuron Transplantation. Science 2010, 327, 1145-1148. [CrossRef] [PubMed]

9. Tang, Y.; Stryker, M.P.; Alvarez-Buylla, A.; Espinosa, J.S. Cortical plasticity induced by transplantation of embryonic somatostatin or parvalbumin interneurons. Proc. Natl. Acad. Sci. USA 2014, 111, 18339-18344. [CrossRef]

10. Morales, B.; Choi, S.Y.; Kirkwood, A. Dark rearing alters the development of GABAergic transmission in visual cortex. J. Neurosci. 2002, 22, 8084-8090. [CrossRef] [PubMed]

11. Cancedda, L.; Putignano, E.; Sale, A.; Viegi, A.; Berardi, N.; Maffei, L. Acceleration of visual system development by environmental enrichment. J. Neurosci. 2004, 24, 4840-4848. [CrossRef]

12. Sale, A.; Putignano, E.; Cancedda, L.; Landi, S.; Cirulli, F.; Berardi, N.; Maffei, L. Enriched environment and acceleration of visual system development. Neuropharmacology 2004, 47, 649-660. [CrossRef] [PubMed]

13. Baroncelli, L.; Scali, M.; Sansevero, G.; Olimpico, F.; Manno, I.; Costa, M.; Sale, A. Experience affects critical period plasticity in the visual cortex through an epigenetic regulation of histone post-translational modifications. J. Neurosci. 2016, 36, 3430-3440. [CrossRef]

14. Huang, Z.J.; Kirkwood, A.; Pizzorusso, T.; Porciatti, V.; Morales, B.; Bear, M.F.; Maffei, L.; Tonegawa, S. BDNF regulates the maturation of inhibition and the critical period of plasticity in mouse visual cortex. Cell 1999, 98, 739-755. [CrossRef]

15. Gu, Y.; Huang, S.; Chang, M.C.; Worley, P.; Kirkwood, A.; Quinlan, E.M. Obligatory role for the immediate early gene NARP in critical period plasticity. Neuron 2013, 79, 335-346. [CrossRef] [PubMed]

16. Gu, Y.; Tran, T.; Murase, S.; Borrell, A.; Kirkwood, A.; Quinlan, E.M. Neuregulin-dependent regulation of fast-spiking interneuron excitability controls the timing of the critical period. J. Neurosci. 2016, 36, 10285-10295. [CrossRef]

17. Sugiyama, S.; Di Nardo, A.A.; Aizawa, S.; Matsuo, I.; Volovitch, M.; Prochiantz, A.; Hensch, T.K. Experience-Dependent Transfer of Otx2 Homeoprotein into the Visual Cortex Activates Postnatal Plasticity. Cell 2008, 134, 508-520. [CrossRef]

18. Fawcett, J.W.; Oohashi, T.; Pizzorusso, T. The roles of perineuronal nets and the perinodal extracellular matrix in neuronal function. Nat. Rev. Neurosci. 2019, 20, 451-465. [CrossRef] [PubMed]

19. Dityatev, A.; Schachner, M.; Sonderegger, P. The dual role of the extracellular matrix in synaptic plasticity and homeostasis. Nat. Rev. Neurosci. 2010, 11, 735-746. [CrossRef]

20. Hockfield, S.; McKay, R.D.; Hendry, S.H.; Jones, E.G. A surface antigen that identifies ocular dominance columns in the visual cortex and laminar features of the lateral geniculate nucleus. Cold Spring Harb. Symp. Quant. Biol. 1983, 48, 877-889. [CrossRef]

21. Seeger, G.; Brauer, K.; Härtig, W.; Brückner, G. Mapping of perineuronal nets in the rat brain stained by colloidal iron hydroxide histochemistry and lectin cytochemistry. Neuroscience 1994, 58, 371-388. [CrossRef]

22. Brückner, G.; Schütz, A.; Härtig, W.; Brauer, K.; Paulke, B.R.; Bigl, V. Projection of non-cholinergic basal forebrain neurons ensheathed with perineuronal nets to rat mesocortex. J. Chem. Neuroanat. 1994, 8, 11-18. [CrossRef]

23. Härtig, W.; Brückner, G.; Brauer, K.; Schmidt, C.; Bigl, V. Allocation of perineuronal nets and parvalbumin-, calbindin-D28k- and glutamic acid decarboxylase-immunoreactivity in the amygdala of the rhesus monkey. Brain Res. 1995, 698, 265-269. [CrossRef]

24. Hausen, D.; Brückner, G.; Drlicek, M.; Härtig, W.; Brauer, K.; Bigl, V. Pyramidal cells ensheathed by perineuronal nets in human motor and somatosensory cortex. Neuroreport 1996, 7, 1725-1729. [CrossRef] [PubMed]

25. Ojima, H.; Sakai, M.; Ohyama, J. Molecular heterogeneity of Vicia villosa-recognized perineuronal nets surrounding pyramidal and nonpyramidal neurons in the guinea pig cerebral cortex. Brain Res. 1998, 786, 274-280. [CrossRef]

26. Brückner, G.; Grosche, J.; Hartlage-Rübsamen, M.; Schmidt, S.; Schachner, M. Region and lamina-specific distribution of extracellular matrix proteoglycans, hyaluronan and tenascin-R in the mouse hippocampal formation. J. Chem. Neuroanat. 2003, 26, 37-50. [CrossRef]

27. Carulli, D.; Rhodes, K.E.; Brown, D.J.; Bonnert, T.P.; Pollack, S.J.; Oliver, K.; Strata, P.; Fawcett, J.W. Composition of perineuronal nets in the adult rat cerebellum and the cellular origin of their components. J. Comp. Neurol. 2006, 494, 559-577. [CrossRef]

28. Vidal, E.; Bolea, R.; Tortosa, R.; Costa, C.; Domènech, A.; Monleón, E.; Vargas, A.; Badiola, J.J.; Pumarola, M. Assessment of calcium-binding proteins (Parvalbumin and Calbindin D-28K) and perineuronal nets in normal and scrapie-affected adult sheep brains. J. Virol. Methods 2006, 136, 137-146. [CrossRef] [PubMed]

29. Galtrey, C.M.; Kwok, J.C.F.; Carulli, D.; Rhodes, K.E.; Fawcett, J.W. Distribution and synthesis of extracellular matrix proteoglycans, hyaluronan, link proteins and tenascin-R in the rat spinal cord. Eur. J. Neurosci. 2008, 27, 1373-1390. [CrossRef] [PubMed]

30. Lee, H.; Leamey, C.A.; Sawatari, A. Perineuronal nets play a role in regulating striatal function in the mouse. PLoS ONE 2012, 7 , e32747. [CrossRef]

31. Yamada, J.; Jinno, S. Spatio-temporal differences in perineuronal net expression in the mouse hippocampus, with reference to parvalbumin. Neuroscience 2013, 253, 368-379. [CrossRef]

32. Carstens, K.E.; Phillips, M.L.; Pozzo-Miller, L.; Weinberg, R.J.; Dudek, S.M. Perineuronal nets suppress plasticity of excitatory synapses on CA2 pyramidal neurons. J. Neurosci. 2016, 36, 6312-6320. [CrossRef] [PubMed] 
33. Fech, T.; Calderón-Garcidueñas, L.; Kulesza, R.J. Characterization of the superior olivary complex of Canis lupus domesticus. Hear. Res. 2017, 351, 130-140. [CrossRef]

34. Mirzadeh, Z.; Alonge, K.M.; Cabrales, E.; Herranz-Pérez, V.; Scarlett, J.M.; Brown, J.M.; Hassouna, R.; Matsen, M.E.; Nguyen, H.T.; Garcia-Verdugo, J.M.; et al. Perineuronal net formation during the critical period for neuronal maturation in the hypothalamic arcuate nucleus. Nat. Metab. 2019, 1, 212-221. [CrossRef] [PubMed]

35. Marchand, A.; Schwartz, C. Perineuronal net expression in the brain of a hibernating mammal. Brain Struct. Funct. 2020, 225, 45-56. [CrossRef]

36. Härtig, W.; Brauer, K.; Bigl, V.; Brückner, G. Chondroitin sulfate proteoglycan-immunoreactivity of lectin-labeled perineuronal nets around parvalbumin-containing neurons. Brain Res. 1994, 635, 307-311. [CrossRef]

37. Alpár, A.; Gärtner, U.; Härtig, W.; Brückner, G. Distribution of pyramidal cells associated with perineuronal nets in the neocortex of rat. Brain Res. 2006, 1120, 13-22. [CrossRef]

38. Baker, K.D.; Gray, A.R.; Richardson, R. The development of perineuronal nets around parvalbumin GABAergic neurons in the medial prefrontal cortex and basolateral amygdala of rats. Behav. Neurosci. 2017, 131, 289-303. [CrossRef]

39. Morikawa, S.; Ikegaya, Y.; Narita, M.; Tamura, H. Activation of perineuronal net-expressing excitatory neurons during associative memory encoding and retrieval. Sci. Rep. 2017, 7, 46024. [CrossRef] [PubMed]

40. Härtig, W.; Derouiche, A.; Welt, K.; Brauer, K.; Grosche, J.; Mäder, M.; Reichenbach, A.; Brückner, G. Cortical neurons immunoreactive for the potassium channel Kv3.1b subunit are predominantly surrounded by perineuronal nets presumed as a buffering system for cations. Brain Res. 1999, 842, 15-29. [CrossRef]

41. Morawski, M.; Reinert, T.; Meyer-Klaucke, W.; Wagner, F.E.; Tröger, W.; Reinert, A.; Jäger, C.; Brückner, G.; Arendt, T. Ion exchanger in the brain: Quantitative analysis of perineuronally fixed anionic binding sites suggests diffusion barriers with ion sorting properties. Sci. Rep. 2015, 5, 16471. [CrossRef]

42. Yamaguchi, Y. Lecticans: Organizers of the brain extracellular matrix. Cell. Mol. Life Sci. 2000, 57, 276-289. [CrossRef]

43. Kwok, J.C.F.; Carulli, D.; Fawcett, J.W. In vitro modeling of perineuronal nets: Hyaluronan synthase and link protein are necessary for their formation and integrity. J. Neurochem. 2010, 114, 1447-1459. [CrossRef]

44. Aruffo, A.; Stamenkovic, I.; Melnick, M.; Underhill, C.B.; Seed, B. CD44 is the principal cell surface receptor for hyaluronate. Cell 1990, 61, 1303-1313. [CrossRef]

45. Fowke, T.M.; Karunasinghe, R.N.; Bai, J.-Z.; Jordan, S.; Gunn, A.J.; Dean, J.M. Hyaluronan synthesis by developing cortical neurons in vitro. Sci. Rep. 2017, 7, 44135. [CrossRef] [PubMed]

46. Deepa, S.S.; Carulli, D.; Galtrey, C.; Rhodes, K.; Fukuda, J.; Mikami, T.; Sugahara, K.; Fawcett, J.W. Composition of perineuronal net extracellular matrix in rat brain: A different disaccharide composition for the net-associated proteoglycans. J. Biol. Chem. 2006, 281, 17789-17800. [CrossRef] [PubMed]

47. Happel, M.F.K.; Niekisch, H.; Castiblanco Rivera, L.L.; Ohl, F.W.; Deliano, M.; Frischknecht, R. Enhanced cognitive flexibility in reversal learning induced by removal of the extracellular matrix in auditory cortex. Proc. Natl. Acad. Sci. USA 2014, 111, 2800-2805. [CrossRef] [PubMed]

48. Sun, Z.Y.; Bozzelli, P.L.; Caccavano, A.; Allen, M.; Balmuth, J.; Vicini, S.; Wu, J.; Conant, K. Disruption of perineuronal nets increases the frequency of sharp wave ripple events. Hippocampus 2018, 28, 42-52. [CrossRef] [PubMed]

49. Matthews, R.T.; Kelly, G.M.; Zerillo, C.A.; Gray, G.; Tiemeyer, M.; Hockfield, S. Aggrecan Glycoforms Contribute to the Molecular Heterogeneity of Perineuronal Nets. J. Neurosci. 2002, 22, 7536-7547. [CrossRef]

50. Sugahara, K.; Kitagawa, H. Recent advances in the study of the biosynthesis and functions of sulfated glycosaminoglycans. Curr. Opin. Struct. Biol. 2000, 10, 518-527. [CrossRef]

51. Miyata, S.; Komatsu, Y.; Yoshimura, Y.; Taya, C.; Kitagawa, H. Persistent cortical plasticity by upregulation of chondroitin 6-sulfation. Nat. Neurosci. 2012, 15, 414-422. [CrossRef]

52. Miller, G.M.; Hsieh-Wilson, L.C. Sugar-dependent modulation of neuronal development, regeneration, and plasticity by chondroitin sulfate proteoglycans. Exp. Neurol. 2015, 274, 115-125. [CrossRef] [PubMed]

53. Miyata, S.; Nadanaka, S.; Igarashi, M.; Kitagawa, H. Structural Variation of Chondroitin Sulfate Chains Contributes to the Molecular Heterogeneity of Perineuronal Nets. Front. Integr. Neurosci. 2018, 12, 1-12. [CrossRef]

54. Kitagawa, H.; Tsutsumi, K.; Tone, Y.; Sugahara, K. Developmental regulation of the sulfation profile of chondroitin sulfate chains in the chicken embryo brain. J. Biol. Chem. 1997, 272, 31377-31381. [CrossRef] [PubMed]

55. Carulli, D.; Pizzorusso, T.; Kwok, J.C.F.; Putignano, E.; Poli, A.; Forostyak, S.; Andrews, M.R.; Deepa, S.S.; Glant, T.T.; Fawcett, J.W Animals lacking link protein have attenuated perineuronal nets and persistent plasticity. Brain 2010, 133, 2331-2347. [CrossRef] [PubMed]

56. Foscarin, S.; Raha-Chowdhury, R.; Fawcett, J.W.; Kwok, J.C.F. Brain ageing changes proteoglycan sulfation, rendering perineuronal nets more inhibitory. Aging 2017, 9, 1607-1622. [CrossRef]

57. Wang, H.; Katagiri, Y.; McCann, T.E.; Unsworth, E.; Goldsmith, P.; Yu, Z.X.; Tan, F.; Santiago, L.; Mills, E.M.; Wang, Y.; et al. Chondroitin-4-sulfation negatively regulates axonal guidance and growth. J. Cell Sci. 2008, 121, 3083-3091. [CrossRef]

58. Lin, R.; Rosahl, T.W.; Whiting, P.J.; Fawcett, J.W.; Kwok, J.C.F. 6-Sulphated chondroitins have a positive influence on axonal regeneration. PLoS ONE 2011, 6, e21499. [CrossRef]

59. Sahu, S.; Li, R.; Loers, G.; Schachner, M. Knockdown of chondroitin-4-sulfotransferase-1, but not of dermatan-4-sulfotransferase-1, accelerates regeneration of zebrafish after spinal cord injury. FASEB J. 2019, 33, 2252-2262. [CrossRef] 
60. Beurdeley, M.; Spatazza, J.; Lee, H.H.C.; Sugiyama, S.; Bernard, C.; Di Nardo, A.A.; Hensch, T.K.; Prochiantz, A. Otx2 Binding to Perineuronal Nets Persistently Regulates Plasticity in the Mature Visual Cortex. J. Neurosci. 2012, 32, 9429-9437. [CrossRef]

61. Brown, J.M.; Xia, J.; Zhuang, B.Q.; Cho, K.S.; Rogers, C.J.; Gama, C.I.; Rawat, M.; Tully, S.E.; Uetani, N.; Mason, D.E.; et al. A sulfated carbohydrate epitope inhibits axon regeneration after injury. Proc. Natl. Acad. Sci. USA 2012, 109, 4768-4773. [CrossRef]

62. Despras, G.; Bernard, C.; Perrot, A.; Cattiaux, L.; Prochiantz, A.; Lortat-Jacob, H.; Mallet, J.-M. Toward libraries of biotinylated chondroitin sulfate analogues: From synthesis to in vivo studies. Chem. A Eur. J. 2013, 19, 531-540. [CrossRef] [PubMed]

63. Dick, G.; Tan, C.L.; Nuno Alves, J.; Ehlert, E.M.E.; Miller, G.M.; Hsieh-Wilson, L.C.; Sugahara, K.; Oosterhof, A.; van Kuppevelt, T.H.; Verhaagen, J.; et al. Semaphorin 3A binds to the perineuronal nets via chondroitin sulfate type E motifs in rodent brains. J. Biol. Chem. 2013, 288, 27384-27395. [CrossRef] [PubMed]

64. Meyer-Puttlitz, B.; Milev, P.; Junker, E.; Zimmer, I.; Margolis, R.U.; Margolis, R.K. Chondroitin Sulfate and Chondroitin/Keratan Sulfate Proteoglycans of Nervous Tissue: Developmental Changes of Neurocan and Phosphacan. J. Neurochem. 1995, 65, 2327-2337. [CrossRef]

65. Hirakawa, S.; Oohashi, T.; Su, W.D.; Yoshioka, H.; Murakami, T.; Arata, J.; Ninomiya, Y. The brain link protein-1 (BRAL1): cDNA cloning, genomic structure, and characterization as a novel link protein expressed in adult brain. Biochem. Biophys. Res. Commun. 2000, 276, 982-989. [CrossRef] [PubMed]

66. Bekku, Y.; Su, W.-D.; Hirakawa, S.; Fässler, R.; Ohtsuka, A.; Kang, J.S.; Sanders, J.; Murakami, T.; Ninomiya, Y.; Oohashi, T. Molecular cloning of Bral2, a novel brain-specific link protein, and immunohistochemical colocalization with brevican in perineuronal nets. Mol. Cell. Neurosci. 2003, 24, 48-159. [CrossRef]

67. Ogawa, H.; Oohashi, T.; Sata, M.; Bekku, Y.; Hirohata, S.; Nakamura, K.; Yonezawa, T.; Kusachi, S.; Shiratori, Y.; Ninomiya, Y. Lp3/Hapln3, a novel link protein that co-localizes with versican and is coordinately up-regulated by platelet-derived growth factor in arterial smooth muscle cells. Matrix Biol. 2004, 23, 287-298. [CrossRef] [PubMed]

68. Oohashi, T.; Edamatsu, M.; Bekku, Y.; Carulli, D. The hyaluronan and proteoglycan link proteins: Organizers of the brain extracellular matrix and key molecules for neuronal function and plasticity. Exp. Neurol. 2015, 274, 134-144. [CrossRef]

69. Lundell, A.; Olin, A.I.; Mörgelin, M.; al-Karadaghi, S.; Aspberg, A.; Logan, D.T. Structural basis for interactions between tenascins and lectican C-type lectin domains: Evidence for a crosslinking role for tenascins. Structure 2004, 12, 1495-1506. [CrossRef] [PubMed]

70. Weber, P.; Bartsch, U.; Rasband, M.N.; Czaniera, R.; Lang, Y.; Bluethmann, H.; Margolis, R.U.; Levinson, S.R.; Shrager, P.; Montag, D.; et al. Mice deficient for tenascin-R display alterations of the extracellular matrix and decreased axonal conduction velocities in the CNS. J. Neurosci. 1999, 19, 4245-4262. [CrossRef]

71. Brückner, G.; Grosche, J.; Schmidt, S.; Härtig, W.; Margolis, R.U.; Delpech, B.; Seidenbecher, C.I.; Czaniera, R.; Schachner, M. Postnatal development of perineuronal nets in wild-type mice and in a mutant deficient in tenascin-R. J. Comp. Neurol. 2000, 428, 616-629. [CrossRef]

72. Miller, B.; Sheppard, A.M.; Bicknese, A.R.; Pearlman, A.L. Chondroitin sulfate proteoglycans in the developing cerebral cortex: The distribution of neurocan distinguishes forming afferent and efferent axonal pathways. J. Comp. Neurol. 1995, 355, 615-628. [CrossRef]

73. Pearlman, A.L.; Sheppard, A.M. Extracellular matrix in early cortical development. Prog. Brain Res. 1996, 108, 117-134.

74. Carulli, D.; Rhodes, K.E.; Fawcett, J.W. Upregulation of aggrecan, link protein 1, and hyaluronan synthases during formation of perineuronal nets in the rat cerebellum. J. Comp. Neurol. 2007, 501, 83-94. [CrossRef]

75. Bekku, Y.; Saito, M.; Moser, M.; Fuchigami, M.; Maehara, A.; Nakayama, M.; Kusachi, S.; Ninomiya, Y.; Oohashi, T. Bral2 is indispensable for the proper localization of brevican and the structural integrity of the perineuronal net in the brainstem and cerebellum. J. Comp. Neurol. 2012, 520, 1721-1736. [CrossRef]

76. Rowlands, D.; Lensjø, K.K.; Dinh, T.; Yang, S.; Andrews, M.R.; Hafting, T.; Fyhn, M.; Fawcett, J.W.; Dick, G. Aggrecan Directs Extracellular Matrix-Mediated Neuronal Plasticity. J. Neurosci. 2018, 38, 10102-10113. [CrossRef]

77. Eill, G.J.; Sinha, A.; Morawski, M.; Viapiano, M.S.; Matthews, R.T. The protein tyrosine phosphatase RPTP $\xi /$ phosphacan is critical for perineuronal net structure. J. Biol. Chem. 2020, 295, 955-968. [CrossRef] [PubMed]

78. Canoll, P.D.; Barnea, G.; Levy, J.B.; Sap, J.; Ehrlich, M.; Silvennoinen, O.; Schlessinger, J.; Musacchio, J.M. The expression of a novel receptor-type tyrosine phosphatase suggests a role in morphogenesis and plasticity of the nervous system. Dev. Brain Res. 1993, 75, 293-298. [CrossRef]

79. Shintani, T.; Watanabe, E.; Maeda, N.; Noda, M. Neurons as well as astrocytes express proteoglycan-type protein tyrosine phosphatase $\zeta / R P T P \beta$ : Analysis of mice in which the PTP $/ / R P T P \beta$ gene was replaced with the LacZ gene. Neurosci. Lett. 1998, 247, 135-138. [CrossRef]

80. Zhou, X.-H.; Brakebusch, C.; Matthies, H.; Oohashi, T.; Hirsch, E.; Moser, M.; Krug, M.; Seidenbecher, C.I.; Boeckers, T.M.; Rauch, U.; et al. Neurocan Is Dispensable for Brain Development. Mol. Cell. Biol. 2001, 21, 5970-5978. [CrossRef]

81. Brakebusch, C.; Seidenbecher, C.I.; Asztely, F.; Rauch, U.; Matthies, H.; Meyer, H.; Krug, M.; Böckers, T.M.; Zhou, X.; Kreutz, M.R.; et al. Brevican-Deficient Mice Display Impaired Hippocampal CA1 Long-Term Potentiation but Show No Obvious Deficits in Learning and Memory. Mol. Cell. Biol. 2002, 22, 7417-7427. [CrossRef]

82. Rauch, U.; Zhou, X.H.; Roos, G. Extracellular matrix alterations in brains lacking four of its components. Biochem. Biophys. Res. Commun. 2005, 328, 608-617. [CrossRef] [PubMed] 
83. Geissler, M.; Gottschling, C.; Aguado, A.; Rauch, U.; Wetzel, C.H.; Hatt, H.; Faissner, A. Primary Hippocampal Neurons, Which Lack Four Crucial Extracellular Matrix Molecules, Display Abnormalities of Synaptic Structure and Function and Severe Deficits in Perineuronal Net Formation. J. Neurosci. 2013, 33, 7742-7755. [CrossRef] [PubMed]

84. Gottschling, C.; Wegrzyn, D.; Denecke, B.; Faissner, A. Elimination of the four extracellular matrix molecules tenascin-C, tenascin-R, brevican and neurocan alters the ratio of excitatory and inhibitory synapses. Sci. Rep. 2019, 9, 13939. [CrossRef]

85. Apostolova, I.; Irintchev, A.; Schachner, M. Tenascin-R restricts posttraumatic remodeling of motoneuron innervation and functional recovery after spinal cord injury in adult mice. J. Neurosci. 2006, 26, 7849-7859. [CrossRef] [PubMed]

86. Pizzorusso, T.; Medini, P.; Berardi, N.; Chierzi, S.; Fawcett, J.W.; Maffei, L. Reactivation of ocular dominance plasticity in the adult visual cortex. Science 2002, 298, 1248-1251. [CrossRef] [PubMed]

87. McRae, P.A.; Rocco, M.M.; Kelly, G.; Brumberg, J.C.; Matthews, R.T. Sensory Deprivation Alters Aggrecan and Perineuronal Net Expression in the Mouse Barrel Cortex. J. Neurosci. 2007, 27, 5405-5413. [CrossRef] [PubMed]

88. Ueno, H.; Suemitsu, S.; Okamoto, M.; Matsumoto, Y.; Ishihara, T. Sensory experience-dependent formation of perineuronal nets and expression of Cat-315 immunoreactive components in the mouse somatosensory cortex. Neuroscience 2017, 355, 161-174. [CrossRef]

89. Kalb, R.G.; Hockfield, S. Molecular evidence for early activity-dependent development of hamster motor neurons. J. Neurosci. 1988, 8, 2350-2360. [CrossRef]

90. Reinhard, S.M.; Abundez-Toledo, M.; Espinoza, K.; Razak, K.A. Effects of developmental noise exposure on inhibitory cell densities and perineuronal nets in A1 and AAF of mice. Hear. Res. 2019, 381, 107781. [CrossRef]

91. Ueno, H.; Suemitsu, S.; Okamoto, M.; Matsumoto, Y.; Ishihara, T. Parvalbumin neurons and perineuronal nets in the mouse prefrontal cortex. Neuroscience 2017, 343, 115-127. [CrossRef]

92. Kolb, B.; Gibb, R. Plasticity in the prefrontal cortex of adult rats. Front. Cell. Neurosci. 2015, 9, 15. [CrossRef]

93. Sigal, Y.M.; Bae, H.; Bogart, L.J.; Hensch, T.K.; Zhuang, X. Structural maturation of cortical perineuronal nets and their perforating synapses revealed by superresolution imaging. Proc. Natl. Acad. Sci. USA 2019, 116, 7071-7076. [CrossRef] [PubMed]

94. Richter, R.P.; Baranova, N.S.; Day, A.J.; Kwok, J.C. Glycosaminoglycans in extracellular matrix organisation: Are concepts from soft matter physics key to understanding the formation of perineuronal nets? Curr. Opin. Struct. Biol. 2018, 50, 65-74. [CrossRef]

95. Gogolla, N.; Caroni, P.; Lüthi, A.; Herry, C. Perineuronal nets protect fear memories from erasure. Science 2009, 325, 1258-1261. [CrossRef] [PubMed]

96. Nowicka, D.; Soulsby, S.; Skangiel-Kramska, J.; Glazewski, S. Parvalbumin-containing neurons, perineuronal nets and experiencedependent plasticity in murine barrel cortex. Eur. J. Neurosci. 2009, 30, 2053-2063. [CrossRef]

97. Balmer, T.S.; Carels, V.M.; Frisch, J.L.; Nick, T.A. Modulation of perineuronal nets and parvalbumin with developmental song learning. J. Neurosci. 2009, 29, 12878-12885. [CrossRef]

98. Cornez, G.; Collignon, C.; Müller, W.; Cornil, C.A.; Ball, G.F.; Balthazart, J. Development of perineuronal nets during ontogeny correlates with sensorimotor vocal learning in canaries. Eneuro 2020, 7. [CrossRef] [PubMed]

99. Cornez, G.; Shevchouk, O.T.; Ghorbanpoor, S.; Ball, G.F.; Cornil, C.A.; Balthazart, J. Testosterone stimulates perineuronal nets development around parvalbumin cells in the adult canary brain in parallel with song crystallization. Horm. Behav. 2020, 119, 104643. [CrossRef]

100. Pizzorusso, T.; Medini, P.; Landi, S.; Baldini, S.; Berardi, N.; Maffei, L. Structural and functional recovery from early monocular deprivation in adult rats. Proc. Natl. Acad. Sci. USA 2006, 103, 8517-8522. [CrossRef] [PubMed]

101. Fawcett, J.W. The extracellular matrix in plasticity and regeneration after CNS injury and neurodegenerative disease. Prog. Brain Res. 2015, 218, 213-226.

102. Pechtel, P.; Pizzagalli, D.A. Effects of early life stress on cognitive and affective function: An integrated review of human literature. Psychopharmacology 2011, 214, 55-70. [CrossRef] [PubMed]

103. Teicher, M.H.; Ohashi, K.; Lowen, S.B.; Polcari, A.; Fitzmaurice, G.M. Mood dysregulation and affective instability in emerging adults with childhood maltreatment: An ecological momentary assessment study. J. Psychiatr. Res. 2015, 70, 1-8. [CrossRef]

104. Page, C.E.; Coutellier, L. Adolescent Stress Disrupts the Maturation of Anxiety-related Behaviors and Alters the Developmental Trajectory of the Prefrontal Cortex in a Sex- and Age-specific Manner. Neuroscience 2018, 390, 265-277. [CrossRef]

105. Santiago, A.N.; Lim, K.Y.; Opendak, M.; Sullivan, R.M.; Aoki, C. Early life trauma increases threat response of peri-weaning rats, reduction of axo-somatic synapses formed by parvalbumin cells and perineuronal net in the basolateral nucleus of amygdala. $J$. Comp. Neurol. 2018, 526, 2647-2664. [CrossRef]

106. Riga, D.; Kramvis, I.; Koskinen, M.K.; van Bokhoven, P.; van der Harst, J.E.; Heistek, T.S.; Jaap Timmerman, A.; van Nierop, P.; van der Schors, R.C.; Pieneman, A.W.; et al. Hippocampal extracellular matrix alterations contribute to cognitive impairment associated with a chronic depressive-like state in rats. Sci. Transl. Med. 2017, 9, eaai8753. [CrossRef] [PubMed]

107. Murthy, S.; Kane, G.A.; Katchur, N.J.; Mejia, P.S.L.; Obiofuma, G.; Buschman, T.J.; McEwen, B.S.; Gould, E. Perineuronal Nets, Inhibitory Interneurons, and Anxiety-Related Ventral Hippocampal Neuronal Oscillations Are Altered by Early Life Adversity. Biol. Psychiatry 2019, 85, 1011-1020. [CrossRef]

108. Guadagno, A.; Verlezza, S.; Long, H.; Wong, T.P.; Walker, C.D. It is all in the right amygdala: Increased synaptic plasticity and perineuronal nets in male, but not female, juvenile rat pups after exposure to early-life stress. J. Neurosci. 2020, 40, 8276-8291. [CrossRef] 
109. Felt, B.T.; Lozoff, B. Brain iron and behavior of rats are not normalized by treatment of iron deficiency anemia during early development. J. Nutr. 1996, 126, 693-701. [CrossRef] [PubMed]

110. Felt, B.T.; Beard, J.L.; Schallert, T.; Shao, J.; Aldridge, J.W.; Connor, J.R.; Georgieff, M.K.; Lozoff, B. Persistent neurochemical and behavioral abnormalities in adulthood despite early iron supplementation for perinatal iron deficiency anemia in rats. Behav. Brain Res. 2006, 171, 261-270. [CrossRef] [PubMed]

111. Schmidt, A.T.; Waldow, K.J.; Grove, W.M.; Salinas, J.A.; Georgieff, M.K. Dissociating the Long-Term Effects of Fetal/Neonatal Iron Deficiency on Three Types of Learning in the Rat. Behav. Neurosci. 2007, 121, 475-482. [CrossRef]

112. Riggins, T.; Miller, N.C.; Bauer, P.J.; Georgieff, M.K.; Nelson, C.A. Consequences of low neonatal iron status due to maternal diabetes mellitus on explicit memory performance in childhood. Dev. Neuropsychol. 2009, 34, 762-779. [CrossRef] [PubMed]

113. Jorgenson, L.A.; Wobken, J.D.; Georgieff, M.K. Perinatal Iron Deficiency Alters Apical Dendritic Growth in Hippocampal CA1 Pyramidal Neurons. Dev. Neurosci. 2003, 25, 412-420. [CrossRef] [PubMed]

114. Brunette, K.E.; Tran, P.V.; Wobken, J.D.; Carlson, E.S.; Georgieff, M.K. Gestational and neonatal iron deficiency alters apical dendrite structure of CA1 pyramidal neurons in adult rat hippocampus. Dev. Neurosci. 2010, 32, 238-248. [CrossRef]

115. Fretham, S.J.B.; Carlson, E.S.; Wobken, J.; Tran, P.V.; Petryk, A.; Georgieff, M.K. Temporal manipulation of transferrin-receptor-1dependent iron uptake identifies a sensitive period in mouse hippocampal neurodevelopment. Hippocampus 2012, 22, 1691-1702. [CrossRef]

116. Umemori, J.; Winkel, F.; Castrén, E.; Karpova, N.N. Distinct effects of perinatal exposure to fluoxetine or methylmercury on parvalbumin and perineuronal nets, the markers of critical periods in brain development. Int. J. Dev. Neurosci. 2015, 44, 55-64. [CrossRef]

117. Ko, M.C.; Lee, L.J.H.; Li, Y.; Lee, L.J. Long-term consequences of neonatal fluoxetine exposure in adult rats. Dev. Neurobiol. 2014, 74, 1038-1051. [CrossRef]

118. Tzakis, N.; Holahan, M.R. Social Memory and the Role of the Hippocampal CA2 Region. Front. Behav. Neurosci. 2019, 13, 233. [CrossRef] [PubMed]

119. Dudek, S.M.; Alexander, G.M.; Farris, S. Rediscovering area CA2: Unique properties and functions. Nat. Rev. Neurosci. 2016, 17, 89-102. [CrossRef]

120. Giger, R.J.; Pasterkamp, R.J.; Heijnen, S.; Holtmaat, A.J.G.D.; Verhaagen, J. Anatomical distribution of the chemorepellent semaphorin III/collapsin- 1 in the adult rat and human brain: Predominant expression in structures of the olfactory-hippocampal pathway and the motor system. J. Neurosci. Res. 1998, 52, 27-42. [CrossRef]

121. Vo, T.; Carulli, D.; Ehlert, E.M.E.; Kwok, J.C.F.; Dick, G.; Mecollari, V.; Moloney, E.B.; Neufeld, G.; de Winter, F.; Fawcett, J.W.; et al. The chemorepulsive axon guidance protein semaphorin3A is a constituent of perineuronal nets in the adult rodent brain. Mol. Cell. Neurosci. 2013, 56, 186-200. [CrossRef]

122. Nadanaka, S.; Miyata, S.; Yaqiang, B.; Tamura, J.-I.; Habuchi, O.; Kitagawa, H. Reconsideration of the semaphorin-3a binding motif found in chondroitin sulfate using galnac4s-6st-knockout mice. Biomolecules 2020, 10, 1499. [CrossRef]

123. Yang, S.; Hilton, S.; Nuno Alves, J.; Saksida, L.M.; Bussey, T.; Matthews, R.T.; Kitagawa, H.; Spillantini, M.G.; Kwok, J.C.F.; Fawcett, J.W. Antibody recognizing 4-sulfated chondroitin sulfate proteoglycans restores memory in tauopathy-induced neurodegeneration. Neurobiol. Aging 2017, 59, 197-209. [CrossRef]

124. Boggio, E.M.; Ehlert, E.M.; Lupori, L.; Moloney, E.B.; De Winter, F.; Vander Kooi, C.W.; Baroncelli, L.; Mecollari, V.; Blits, B.; Fawcett, J.W.; et al. Inhibition of Semaphorin3A Promotes Ocular Dominance Plasticity in the Adult Rat Visual Cortex. Mol. Neurobiol. 2019, 56, 5987-5997. [CrossRef] [PubMed]

125. Janssen, B.J.C.; Malinauskas, T.; Weir, G.A.; Zameel Cader, M.; Siebold, C.; Jones, E.Y. Neuropilins lock secreted semaphorins onto plexins in a ternary signaling complex. Nat. Struct. Mol. Biol. 2012, 19, 1293-1299. [CrossRef]

126. Gutekunst, C.-A.; Steward, E.N.; Gross, R.E. Immunohistochemical distribution of PlexinA4 in the adult rat central nervous system. Front. Neuroanat. 2010, 4, 1-17. [CrossRef]

127. Saywell, V.; Cioni, J.M.; Ango, F. Developmental gene expression profile of axon guidance cues in purkinje cells during cerebellar circuit formation. Cerebellum 2014, 13, 307-317. [CrossRef] [PubMed]

128. Holtmaat, A.J.G.D.; Gorter, J.A.; De Wit, J.; Tolner, E.A.; Spijker, S.; Giger, R.J.; Da Silva, F.H.L.; Verhaagen, J. Transient downregulation of Sema3A mRNA in a rat model for temporal lobe epilepsy: A novel molecular event potentially contributing to mossy fiber sprouting. Exp. Neurol. 2003, 182, 142-150. [CrossRef]

129. Djerbal, L.; Vivès, R.; Lopin-Bon, C.; Richter, R.; Kwok, J.C.; Lortat-Jacob, H. Semaphorin 3A binding to chondroitin sulfate E enhances the biological activity of the protein, and cross-links and rigidifies glycosaminoglycan matrices. BioRxiv 2019. [CrossRef]

130. De Wit, J.; Toonen, R.F.; Verhaagen, J.; Verhage, M. Vesicular trafficking of semaphorin 3A is activity-dependent and differs between axons and dendrites. Traffic 2006, 7, 1060-1077. [CrossRef] [PubMed]

131. Pasterkamp, R.J.; Giger, R.; Ruitenberg, M.-J.; Holtmaat, A.; De Wit, J.; De Winter, F.; Verhaagen, J. Expression of the gene encoding the chemorepellent semaphorin III is induced in the fibroblast component of neural scar tissue formed following injuries of adult but not neonatal CNS. Mol. Cell. Neurosci. 1999, 13, 143-166. [CrossRef] [PubMed]

132. Lee, H.H.C.; Bernard, C.; Ye, Z.; Acampora, D.; Simeone, A.; Prochiantz, A.; Di Nardo, A.A.; Hensch, T.K. Genetic Otx2 mis-localization delays critical period plasticity across brain regions. Mol. Psychiatry 2017, 22, 680-688. [CrossRef] [PubMed] 
133. Bernard, C.; Vincent, C.; Testa, D.; Bertini, E.; Ribot, J.; Di Nardo, A.A.; Volovitch, M.; Prochiantz, A. A Mouse Model for Conditional Secretion of Specific Single-Chain Antibodies Provides Genetic Evidence for Regulation of Cortical Plasticity by a Non-cell Autonomous Homeoprotein Transcription Factor. PLoS Genet. 2016, 12, e1006035. [CrossRef] [PubMed]

134. Johansson, P.A.; Irmler, M.; Acampora, D.; Beckers, J.; Simeone, S.; Götz, M. The transcription factor Otx2 regulates choroid plexus development and function. Development 2013, 140, 1055-1066. [CrossRef] [PubMed]

135. Spatazza, J.; Lee, H.H.C.; Di Nardo, A.A.; Tibaldi, L.; Joliot, A.; Hensch, T.K.; Prochiantz, A. Choroid-Plexus-Derived Otx2 Homeoprotein Constrains Adult Cortical Plasticity. Cell Rep. 2013, 3, 1815-1823. [CrossRef]

136. Hou, X.; Yoshioka, N.; Tsukano, H.; Sakai, A.; Miyata, S.; Watanabe, Y.; Yanagawa, Y.; Sakimura, K.; Takeuchi, K.; Kitagawa, H.; et al. Chondroitin Sulfate Is Required for Onset and Offset of Critical Period Plasticity in Visual Cortex. Sci. Rep. 2017, 7, 1-17. [CrossRef]

137. Barreto, G.; Schäfer, A.; Marhold, J.; Stach, D.; Swaminathan, S.K.; Handa, V.; Döderlein, G.; Maltry, N.; Wu, W.; Lyko, F.; et al. Gadd45a promotes epigenetic gene activation by repair-mediated DNA demethylation. Nature 2007, 445, 671-675. [CrossRef]

138. Ma, D.K.; Guo, J.U.; Ming, G.L.; Song, H. DNA excision repair proteins and Gadd45 as molecular players for active DNA demethylation. Cell Cycle 2009, 8, 1526-1531. [CrossRef] [PubMed]

139. Gavin, D.P.; Akbarian, S. Epigenetic and post-transcriptional dysregulation of gene expression in schizophrenia and related disease. Neurobiol. Dis. 2012, 46, 255-262. [CrossRef]

140. Leach, P.T.; Poplawski, S.G.; Kenney, J.W.; Hoffman, B.; Liebermann, D.A.; Abel, T.; Gould, T.J. Gadd45b knockout mice exhibit selective deficits in hippocampus-dependent long-term memory. Learn. Mem. 2012, 19, 319-324. [CrossRef] [PubMed]

141. Sultan, F.A.; Wang, J.; Tront, J.; Liebermann, D.A.; David Sweatt, J. Genetic deletion of gadd45b, a regulator of active DNA demethylation, enhances long-term memory and synaptic plasticity. J. Neurosci. 2012, 32, 17059-17066. [CrossRef]

142. Apulei, J.; Kim, N.; Testa, D.; Ribot, J.; Morizet, D.; Bernard, C.; Jourdren, L.; Blugeon, C.; Di Nardo, A.A.; Prochiantz, A. Non-cell Autonomous OTX2 Homeoprotein Regulates Visual Cortex Plasticity Through Gadd45b/g. Cereb. Cortex 2019, 29, $2384-2395$. [CrossRef]

143. Djerbal, L.; Lortat-Jacob, H.; Kwok, J.C.F. Chondroitin sulfates and their binding molecules in the central nervous system. Glycoconjug. J. 2017, 34, 363-376. [CrossRef] [PubMed]

144. Vallet, S.D.; Clerc, O.; Ricard-Blum, S. Glycosaminoglycan-Protein Interactions: The First Draft of the Glycosaminoglycan Interactome. J. Histochem. Cytochem. 2020, 69, 93-104. [CrossRef]

145. Sugahara, K.; Mikami, T. Chondroitin/dermatan sulfate in the central nervous system. Curr. Opin. Struct. Biol. 2007, 17, 536-545. [CrossRef] [PubMed]

146. Sullivan, C.S.; Gotthard, I.; Wyatt, E.V.; Bongu, S.; Mohan, V.; Weinberg, R.J.; Maness, P.F. Perineuronal Net Protein Neurocan Inhibits NCAM/EphA3 Repellent Signaling in GABAergic Interneurons. Sci. Rep. 2018, 8, 6143. [CrossRef] [PubMed]

147. Orlando, C.; Ster, J.; Gerber, U.; Fawcett, J.W.; Raineteau, O. Perisynaptic chondroitin sulfate proteoglycans restrict structural plasticity in an integrin-dependent manner. J. Neurosci. 2012, 32, 18009-18017. [CrossRef] [PubMed]

148. De Vivo, L.; Landi, S.; Panniello, M.; Baroncelli, L.; Chierzi, S.; Mariotti, L.; Spolidoro, M.; Pizzorusso, T.; Maffei, L.; Ratto, G.M. Extracellular matrix inhibits structural and functional plasticity of dendritic spines in the adult visual cortex. Nat. Commun. 2013, 4, 1484. [CrossRef]

149. Tan, C.L.; Kwok, J.C.F.; Patani, R.; Ffrench-Constant, C.; Chandran, S.; Fawcett, J.W. Integrin activation promotes axon growth on inhibitory chondroitin sulfate proteoglycans by enhancing integrin signaling. J. Neurosci. 2011, 31, 6289-6295. [CrossRef]

150. Favuzzi, E.; Marques-Smith, A.; Deogracias, R.; Winterflood, C.M.; Sánchez-Aguilera, A.; Mantoan, L.; Maeso, P.; Fernandes, C.; Ewers, H.; Rico, B. Activity-Dependent Gating of Parvalbumin Interneuron Function by the Perineuronal Net Protein Brevican. Neuron 2017, 95, 639-655. [CrossRef]

151. Frischknecht, R.; Heine, M.; Perrais, D.; Seidenbecher, C.I.; Choquet, D.; Gundelfinger, E.D. Brain extracellular matrix affects AMPA receptor lateral mobility and short-term synaptic plasticity. Nat. Neurosci. 2009, 12, 897-904. [CrossRef]

152. Senkov, O.; Andjus, P.; Radenovic, L.; Soriano, E.; Dityatev, A. Neural ECM molecules in synaptic plasticity, learning, and memory. Progr. Brain Res. 2014, 214, 53-80.

153. Fisher, D.; Xing, B.; Dill, J.; Li, H.; Hiep Hoang, H.; Zhao, Z.; Yang, X.-L.; Bachoo, R.; Cannon, S.; Longo, F.M.; et al. Leukocyte common antigen-related phosphatase is a functional receptor for chondroitin sulfate proteoglycan axon growth inhibitors. $J$. Neurosci. 2011, 31, 14051-14066. [CrossRef] [PubMed]

154. Lang, B.T.; Cregg, J.M.; DePaul, M.A.; Tran, A.P.; Xu, K.; Dyck, S.M.; Madalena, K.M.; Brown, B.P.; Weng, Y.-L.; Li, S.; et al. Modulation of the proteoglycan receptor PTPo promotes recovery after spinal cord injury. Nature 2015, 518, 404-408. [CrossRef]

155. Dickendesher, T.L.; Baldwin, K.T.; Mironova, Y.A.; Koriyama, Y.; Raiker, S.J.; Askew, K.L.; Wood, A.; Geoffroy, C.G.; Zheng, B.; Liepmann, C.D.; et al. NgR1 and NgR3 are receptors for chondroitin sulfate proteoglycans. Nat. Neurosci. 2012, 15, 703-712. [CrossRef]

156. Golgi, C. Intorno alla struttura delle cellule nervose. Boll. Soc. Med. Chir. Pavia 1898, 13, 3-16.

157. Ramón y Cajal, S. Histologie du Systeme Nerveux de l'Homme et Des Vertebres; Maloine: Paris, France, 1909.

158. Rambourg, A.; Neutra, M.; Leblond, C.P. Presence of a 'cell coat' rich in carbohydrate at the surface of cells in the rat. Anat. Rec. 1966, 154, 41-71. [CrossRef]

159. Glegg, R.E.; Pearce, R.H. Chemical extraction of metachromatic and periodic acid-Schiff positive carbohydrates from cerebral tissue. J. Comp. Neurol. 1956, 106, 291-297. [CrossRef] [PubMed] 
160. Brauer, K.; Brückner, G.; Leibnitz, L.; Werner, L. Structural and cytochemical features of perineuronal glial nets in the rat brain. Acta Histochem. 1984, 74, 53-60. [CrossRef]

161. Steindler, D.A.; Cooper, N.G.F. Wheat germ agglutinin binding sites in the adult mouse cerebellum: Light and electron microscopic studies. J. Comp. Neurol. 1986, 249, 170-185. [CrossRef]

162. Brückner, G.; Brauer, K.; Härtig, W.; Wolff, J.R.; Rickmann, M.J.; Derouiche, A.; Delpech, B.; Girard, N.; Oertel, W.H.; Reichenbach, A. Perineuronal nets provide a polyanionic, glia-associated form of microenvironment around certain neurons in many parts of the rat brain. Glia 1993, 8, 183-200. [CrossRef]

163. Sale, A.; Maya Vetencourt, J.F.; Medini, P.; Cenni, M.C.; Baroncelli, L.; De Pasquale, R.; Maffei, L. Environmental enrichment in adulthood promotes amblyopia recovery through a reduction of intracortical inhibition. Nat. Neurosci. 2007, 10, 679-681. [CrossRef]

164. Foscarin, S.; Ponchione, D.; Pajaj, E.; Leto, K.; Gawlak, M.; Wilczynski, G.M.; Rossi, F.; Carulli, D. Experience-dependent plasticity and modulation of growth regulatory molecules at central synapses. PLoS ONE 2011, 6, e16666. [CrossRef]

165. Donato, F.; Rompani, S.B.; Caroni, P. Parvalbumin-expressing basket-cell network plasticity induced by experience regulates adult learning. Nature 2013, 504, 272-276. [CrossRef]

166. Sale, A.; Berardi, N.; Maffei, L. Environment and brain plasticity: Towards an endogenous pharmacotherapy. Physiol. Rev. 2014, 94, 189-234. [CrossRef] [PubMed]

167. Smith, C.C.; Mauricio, R.; Nobre, L.; Marsh, B.; Wüst, R.C.I.; Rossiter, H.B.; Ichiyama, R.M. Differential regulation of perineuronal nets in the brain and spinal cord with exercise training. Brain Res. Bull. 2015, 111, 20-26. [CrossRef] [PubMed]

168. Miyata, S.; Akagi, A.; Hayashi, N.; Watanabe, K.; Oohira, A. Activity-dependent regulation of a chondroitin sulfate proteoglycan 6B4 phosphacan/RPTP $\beta$ in the hypothalamic supraoptic nucleus. Brain Res. 2004, 1017, 163-171. [CrossRef] [PubMed]

169. Theodosis, D.T.; Poulain, D.A. Activity-dependent neuronal-glial and synaptic plasticity in the adult mammalian hypothalamus Neuroscience 1993, 57, 501-535. [CrossRef]

170. Maya-Vetencourt, J.F.; Sale, A.; Viegi, A.; Baroncelli, L.; De Pasquale, R.; O’Leary, O.F.; Castrén, E.; Maffei, L. The antidepressant fluoxetine restores plasticity in the adult visual cortex. Science 2008, 320, 385-388. [CrossRef]

171. Guirado, R.; Perez-Rando, M.; Sanchez-Matarredona, D.; Castrén, E.; Nacher, J. Chronic fluoxetine treatment alters the structure, connectivity and plasticity of cortical interneurons. Int. J. Neuropsychopharmacol. 2014, 17, 1635-1646. [CrossRef] [PubMed]

172. Popova, D.; Castrén, E.; Taira, T. Chronic fluoxetine administration enhances synaptic plasticity and increases functional dynamics in hippocampal CA3-CA1 synapses. Neuropharmacology 2017, 126, 250-256. [CrossRef] [PubMed]

173. Harauzov, A.; Spolidoro, M.; DiCristo, G.; De Pasquale, R.; Cancedda, L.; Pizzorusso, T.; Viegi, A.; Berardi, N.; Maffei, L. Reducing Intracortical Inhibition in the Adult Visual Cortex Promotes Ocular Dominance Plasticity. J. Neurosci. 2010, 30, 361-371. [CrossRef] [PubMed]

174. Pantazopoulos, H.; Gisabella, B.; Rexrode, L.; Benefield, D.; Yildiz, E.; Seltzer, P.; Valeri, J.; Chelini, G.; Reich, A.; Ardelt, M.; et al. Circadian rhythms of perineuronal net composition. Eneuro 2020, 7, 1-21. [CrossRef]

175. Chaudhury, D.; Wang, L.M.; Colwell, C.S. Circadian regulation of hippocampal long-term potentiation. J. Biol. Rhythms 2005, 20, 225-236. [CrossRef]

176. Rasch, B.; Born, J. About sleep's role in memory. Physiol. Rev. 2013, 93, 681-766. [CrossRef] [PubMed]

177. Havekes, R.; Park, A.J.; Tudor, J.C.; Luczak, V.G.; Hansen, R.T.; Ferri, S.L.; Bruinenberg, V.M.; Poplawski, S.G.; Day, J.P.; Aton, S.J.; et al. Sleep deprivation causes memory deficits by negatively impacting neuronal connectivity in hippocampal area CA1. Elife 2016, 5, e13424. [CrossRef]

178. Raven, F.; Meerlo, P.; Van der Zee, E.A.; Abel, T.; Havekes, R. A brief period of sleep deprivation causes spine loss in the dentate gyrus of mice. Neurobiol. Learn. Mem. 2019, 160, 83-90. [CrossRef]

179. Morawski, M.; Brückner, M.K.; Riederer, P.; Brückner, G.; Arendt, T. Perineuronal nets potentially protect against oxidative stress. Exp. Neurol. 2004, 188, 309-315. [CrossRef] [PubMed]

180. Cabungcal, J.-H.; Steullet, P.; Morishita, H.; Kraftsik, R.; Cuenod, M.; Hensch, T.K.; Do, K.Q. Perineuronal nets protect fast-spiking interneurons against oxidative stress. Proc. Natl. Acad. Sci. USA 2013, 110, 9130-9135. [CrossRef] [PubMed]

181. Suttkus, A.; Rohn, S.; Weigel, S.; Glöckner, P.; Arendt, T.; Morawski, M. Aggrecan, link protein and tenascin-R are essential components of the perineuronal net to protect neurons against iron-induced oxidative stress. Cell Death Dis. 2014, 5, e1119. [CrossRef]

182. Harkness, J.H.; Bushana, P.N.; Todd, R.P.; Clegern, W.C.; Sorg, B.A.; Wisor, J.P. Sleep disruption elevates oxidative stress in parvalbumin-positive cells of the rat cerebral cortex. Sleep 2019, 42, 1-15. [CrossRef] [PubMed]

183. Faralli, A.; Dagna, F.; Albera, A.; Bekku, Y.; Oohashi, T.; Albera, R.; Rossi, F.; Carulli, D. Modifications of perineuronal nets and remodelling of excitatory and inhibitory afferents during vestibular compensation in the adult mouse. Brain Struct. Funct. 2016, 221, 3193-3209. [CrossRef] [PubMed]

184. Carmichael, S.T.; Archibeque, I.; Luke, L.; Nolan, T.; Momiy, J.; Li, S. Growth-associated gene expression after stroke: Evidence for a growth-promoting region in peri-infarct cortex. Exp. Neurol. 2005, 193, 291-311. [CrossRef]

185. Carulli, D.; Foscarin, S.; Faralli, A.; Pajaj, E.; Rossi, F. Modulation of semaphorin3A in perineuronal nets during structural plasticity in the adult cerebellum. Mol. Cell. Neurosci. 2013, 57, 10-22. [CrossRef]

186. Sánchez-Ventura, J.; Giménez-Llort, L.; Penas, C.; Udina, E. Voluntary wheel running preserves lumbar perineuronal nets, enhances motor functions and prevents hyperreflexia after spinal cord injury. Exp. Neurol. 2021, 336, 113533. [CrossRef] 
187. Banerjee, S.B.; Gutzeit, V.A.; Baman, J.; Aoued, H.S.; Doshi, N.K.; Liu, R.C.; Ressler, K.J. Perineuronal Nets in the Adult Sensory Cortex Are Necessary for Fear Learning. Neuron 2017, 95, 169-179. [CrossRef] [PubMed]

188. Shi, W.; Wei, X.; Wang, X.; Du, S.; Liu, W.; Song, J.; Wang, Y. Perineuronal nets protect long-term memory by limiting activitydependent inhibition from parvalbumin interneurons. Proc. Natl. Acad. Sci. USA 2019, 116, 27063-27073. [CrossRef] [PubMed]

189. Carulli, D.; Broersen, R.; de Winter, F.; Muir, E.M.; Mešković, M.; de Waal, M.; de Vries, S.; Boele, H.-J.; Canto, C.B.; De Zeeuw, C.I.; et al. Cerebellar plasticity and associative memories are controlled by perineuronal nets. Proc. Natl. Acad. Sci. USA 2020, 117, 6855-6865. [CrossRef]

190. Lasek, A.W.; Chen, H.; Chen, W.Y. Releasing Addiction Memories Trapped in Perineuronal Nets. Trends Genet. 2018, 34, 197-208. [CrossRef] [PubMed]

191. Miquel, M.; Vazquez-Sanroman, D.; Carbo-Gas, M.; Gil-Miravet, I.; Sanchis-Segura, C.; Carulli, D.; Manzo, J.; Coria-Avila, G.A. Have we been ignoring the elephant in the room? Seven arguments for considering the cerebellum as part of addiction circuitry. Neurosci. Biobehav. Rev. 2016, 60, 1-11. [CrossRef] [PubMed]

192. Vazquez-Sanroman, D.; Leto, K.; Cerezo-Garcia, M.; Carbo-Gas, M.; Sanchis-Segura, C.; Carulli, D.; Rossi, F.; Miquel, M. The cerebellum on cocaine: Plasticity and metaplasticity. Addict. Biol. 2015, 20, 941-955. [CrossRef]

193. Vazquez-Sanroman, D.; Carbo-Gas, M.; Leto, K.; Cerezo-Garcia, M.; Gil-Miravet, I.; Sanchis-Segura, C.; Carulli, D.; Rossi, F.; Miquel, M. Cocaine-induced plasticity in the cerebellum of sensitised mice. Psychopharmacology 2015, 232, 4455-4467. [CrossRef] [PubMed]

194. Sanchez-Hernandez, A.; Nicolas, C.; Gil-Miravet, I.; Guarque-Chabrera, J.; Solinas, M.; Miquel, M. Time-dependent regulation of perineuronal nets in the cerebellar cortex during abstinence of cocaine-self administration. Psychopharmacologym 2021. [CrossRef]

195. Carbo-Gas, M.; Moreno-Rius, J.; Guarque-Chabrera, J.; Vazquez-Sanroman, D.; Gil-Miravet, I.; Carulli, D.; Hoebeek, F.; De Zeeuw, C.; Sanchis-Segura, C.; Miquel, M. Cerebellar perineuronal nets in cocaine-induced pavlovian memory: Site matters. Neuropharmacology 2017, 125, 166-180. [CrossRef]

196. Van Den Oever, M.C.; Lubbers, B.R.; Goriounova, N.A.; Li, K.W.; Van der Schors, R.C.; Loos, M.; Riga, D.; Wiskerke, J.; Binnekade, R.; Stegeman, M.; et al. Extracellular matrix plasticity and GABAergic inhibition of prefrontal cortex pyramidal cells facilitates relapse to heroin seeking. Neuropsychopharmacology 2010, 35, 2120-2133. [CrossRef] [PubMed]

197. Slaker, M.L.; Jorgensen, E.T.; Hegarty, D.M.; Liu, X.; Kong, Y.; Zhang, F.; Linhardt, R.J.; Brown, T.E.; Aicher, S.A.; Sorg, B.A. Cocaine Exposure Modulates Perineuronal Nets and Synaptic Excitability of Fast-Spiking Interneurons in the Medial Prefrontal Cortex. Eneuro 2018, 5. [CrossRef] [PubMed]

198. Chen, H.; He, D.; Lasek, A.W. Repeated Binge Drinking Increases Perineuronal Nets in the Insular Cortex. Alcohol. Clin. Exp. Res. 2015, 39, 1930-1938. [CrossRef]

199. Cunha-Oliveira, T.; Silva, L.; Silva, A.M.; Moreno, A.J.; Oliveira, C.R.; Santos, M.S. Mitochondrial complex I dysfunction induced by cocaine and cocaine plus morphine in brain and liver mitochondria. Toxicol. Lett. 2013, 219, 298-306. [CrossRef]

200. Kochlamazashvili, G.; Henneberger, C.; Bukalo, O.; Dvoretskova, E.; Senkov, O.; Lievens, P.M.-J.; Westenbroek, R.; Engel, A.K.; Catterall, W.A.; Rusakov, D.A.; et al. The extracellular matrix molecule hyaluronic acid regulates hippocampal synaptic plasticity by modulating postsynaptic L-type Ca2+ channels. Neuron 2010, 67, 116-128. [CrossRef]

201. Hylin, M.J.; Orsi, S.A.; Moore, A.N.; Dash, P.K. Disruption of the perineuronal net in the hippocampus or medial prefrontal cortex impairs fear conditioning. Learn. Mem. 2013, 20, 267-273. [CrossRef] [PubMed]

202. Thompson, E.H.; Lensjø, K.K.; Wigestrand, M.B.; Malthe-Sørenssen, A.; Hafting, T.; Fyhn, M. Removal of perineuronal nets disrupts recall of a remote fear memory. Proc. Natl. Acad. Sci. USA 2018, 115, 607-612. [CrossRef] [PubMed]

203. Romberg, C.; Yang, S.; Melani, R.; Andrews, M.R.; Horner, A.E.; Spillantini, M.G.; Bussey, T.J.; Fawcett, J.W.; Pizzorusso, T.; Saksida, L.M. Depletion of Perineuronal Nets Enhances Recognition Memory and Long-Term Depression in the Perirhinal Cortex. J. Neurosci. 2013, 33, 7057-7065. [CrossRef]

204. Hirono, M.; Watanabe, S.; Karube, F.; Fujiyama, F.; Kawahara, S.; Nagao, S.; Yanagawa, Y.; Misonou, H. Perineuronal Nets in the Deep Cerebellar Nuclei Regulate GABAergic Transmission and Delay Eyeblink Conditioning. J. Neurosci. 2018, 38, 6130-6144. [CrossRef] [PubMed]

205. Bertocchi, I.; Mele, P.; Ferrero, G.; Oberto, A.; Carulli, D.; Eva, C. NPY-Y1 receptor signaling controls spatial learning and perineuronal net expression. Neuropharmacology 2021, 184, 108425. [CrossRef]

206. Kaczmarek, L.; Lapinska-Dzwonek, J.; Szymczak, S. Matrix metalloproteinases in the adult brain physiology: A link between c-Fos, AP-1 and remodeling of neuronal connections? EMBO J. 2002, 21, 6643-6648. [CrossRef]

207. Verslegers, M.; Lemmens, K.; Van Hove, I.; Moons, L. Matrix metalloproteinase-2 and -9 as promising benefactors in development, plasticity and repair of the nervous system. Prog. Neurobiol. 2013, 105, 60-78. [CrossRef]

208. Howell, M.D.; Gottschall, P.E. Lectican proteoglycans, their cleaving metalloproteinases, and plasticity in the central nervous system extracellular microenvironment. Neuroscience 2012, 217, 6-18. [CrossRef] [PubMed]

209. Stamenkovic, V.; Stamenkovic, S.; Jaworski, T.; Gawlak, M.; Jovanovic, M.; Jakovcevski, I.; Wilczynski, G.M.; Kaczmarek, L.; Schachner, M.; Radenovic, L.; et al. The extracellular matrix glycoprotein tenascin-C and matrix metalloproteinases modify cerebellar structural plasticity by exposure to an enriched environment. Brain Struct. Funct. 2017, 222, 393-415. [CrossRef] [PubMed]

210. Murase, S.; Lantz, C.L.; Quinlan, E.M. Light reintroduction after dark exposure reactivates plasticity in adults via perisynaptic activation of MMP-9. Elife 2017, 6, e27345. [CrossRef] 
211. Ganguly, K.; Rejmak, E.; Mikosz, M.; Nikolaev, E.; Knapska, E.; Kaczmarek, L. Matrix metalloproteinase (MMP) 9 transcription in mouse brain induced by fear learning. J. Biol. Chem. 2013, 288, 20978-20991. [CrossRef]

212. Dubey, D.; McRae, P.A.; Rankin-Gee, E.K.; Baranov, E.; Wandrey, L.; Rogers, S.; Porter, B.E. Increased metalloproteinase activity in the hippocampus following status epilepticus. Epilepsy Res. 2017, 132, 50-58. [CrossRef] [PubMed]

213. Yuan, W.; Matthews, R.T.; Sandy, J.D.; Gottschall, P.E. Association between protease-specific proteolytic cleavage of brevican and synaptic loss in the dentate gyrus of kainate-treated rats. Neuroscience 2002, 114, 1091-1101. [CrossRef]

214. Rossier, J.; Bernard, A.; Cabungcal, J.-H.; Perrenoud, Q.; Savoye, A.; Gallopin, T.; Hawrylycz, M.; Cuénod, M.; Do, K.; Urban, A.; et al. Cortical fast-spiking parvalbumin interneurons enwrapped in the perineuronal net express the metallopeptidases Adamts8, Adamts15 and Neprilysin. Mol. Psychiatry 2015, 20, 154-161. [CrossRef] [PubMed]

215. Nguyen, P.T.; Dorman, L.C.; Pan, S.; Vainchtein, I.D.; Han, R.T.; Nakao-Inoue, H.; Taloma, S.E.; Barron, J.J.; Molofsky, A.B.; Kheirbek, M.A.; et al. Microglial Remodeling of the Extracellular Matrix Promotes Synapse Plasticity. Cell 2020, 182, 388-403. [CrossRef]

216. Bolós, M.; Perea, J.R.; Terreros-Roncal, J.; Pallas-Bazarra, N.; Jurado-Arjona, J.; Ávila, J.; Llorens-Martín, M. Absence of microglial CX3CR1 impairs the synaptic integration of adult-born hippocampal granule neurons. Brain. Behav. Immun. 2018, 68, 76-89. [CrossRef] [PubMed]

217. Crapser, J.D.; Ochaba, J.; Soni, N.; Reidling, J.C.; Thompson, L.M.; Green, K.N. Microglial depletion prevents extracellular matrix changes and striatal volume reduction in a model of Huntington's disease. Brain 2020, 143, 266-288. [CrossRef]

218. Karetko-Sysa, M.; Skangiel-Kramska, J.; Nowicka, D. Aging somatosensory cortex displays increased density of WFA-binding perineuronal nets associated with GAD-negative neurons. Neuroscience 2014, 277, 734-746. [CrossRef] [PubMed]

219. Végh, M.J.; Rausell, A.; Loos, M.; Heldring, C.M.; Jurkowski, W.; van Nierop, P.; Paliukhovich, I.; Li, K.W.; del Sol, A.; Smit, A.B.; et al. Hippocampal extracellular matrix levels and stochasticity in synaptic protein expression increase with age and are associated with age-dependent cognitive decline. Mol. Cell. Proteom. 2014, 13, 2975-2985. [CrossRef] [PubMed]

220. Ueno, H.; Takao, K.; Suemitsu, S.; Murakami, S.; Kitamura, N.; Wani, K.; Okamoto, M.; Aoki, S.; Ishihara, T. Age-dependent and region-specific alteration of parvalbumin neurons and perineuronal nets in the mouse cerebral cortex. Neurochem. Int. 2018, 112, 59-70. [CrossRef] [PubMed]

221. Tanaka, Y.; Mizoguchi, K. Influence of aging on chondroitin sulfate proteoglycan expression and neural stem/progenitor cells in rat brain and improving effects of a herbal medicine, yokukansan. Neuroscience 2009, 164, 1224-1234. [CrossRef] [PubMed]

222. Richard, A.D.; Tian, X.L.; El-Saadi, M.W.; Lu, X.H. Erasure of striatal chondroitin sulfate proteoglycan-associated extracellular matrix rescues aging-dependent decline of motor learning. Neurobiol. Aging 2018, 71, 61-71. [CrossRef]

223. Gray, E.; Thomas, T.L.; Betmouni, S.; Scolding, N.; Love, S. Elevated matrix metalloproteinase-9 and degradation of perineuronal nets in cerebrocortical multiple sclerosis plaques. J. Neuropathol. Exp. Neurol. 2008, 67, 888-899. [CrossRef]

224. Pantazopoulos, H.; Berretta, S. In sickness and in health: Perineuronal nets and synaptic plasticity in psychiatric disorders. Neural Plast. 2016, 2016, 9847696. [CrossRef]

225. Testa, D.; Prochiantz, A.; Di Nardo, A.A. Perineuronal nets in brain physiology and disease. Semin. Cell Dev. Biol. 2019, 89, 125-135. [CrossRef] [PubMed]

226. Spijker, S.; Koskinen, M.K.; Riga, D. Incubation of depression: ECM assembly and parvalbumin interneurons after stress. Neurosci. Biobehav. Rev. 2020, 118, 65-79. [CrossRef] [PubMed]

227. Braak, H.; Braak, E. Neuropathological stageing of Alzheimer-related changes. Acta Neuropathol. 1991, 82, 239-259. [CrossRef] [PubMed]

228. Goedert, M.; Sisodia, S.S.; Price, D.L. Neurofibrillary tangles and $\beta$-amyloid deposits in Alzheimer's disease. Curr. Opin. Neurobiol. 1991, 1, 441-447. [CrossRef]

229. Kobayashi, K.; Emson, P.C.; Mountjoy, C.Q. Vicia villosa lectin-positive neurones in human cerebral cortex. Loss in Alzheimer-type dementia. Brain Res. 1989, 498, 170-174. [CrossRef]

230. Baig, S.; Wilcock, G.K.; Love, S. Loss of perineuronal net N-acetylgalactosamine in Alzheimer's disease. Acta Neuropathol. 2005, 110, 393-401. [CrossRef]

231. Crapser, J.D.; Spangenberg, E.E.; Barahona, R.A.; Arreola, M.A.; Hohsfield, L.A.; Green, K.N. Microglia facilitate loss of perineuronal nets in the Alzheimer's disease brain. EBioMedicine 2020, 58, 102919. [CrossRef]

232. Cattaud, V.; Bezzina, C.; Rey, C.C.; Lejards, C.; Dahan, L.; Verret, L. Early disruption of parvalbumin expression and perineuronal nets in the hippocampus of the Tg2576 mouse model of Alzheimer's disease can be rescued by enriched environment. Neurobiol. Aging 2018, 72, 147-158. [CrossRef]

233. Morawski, M.; Brückner, G.; Jäger, C.; Seeger, G.; Arendt, T. Neurons associated with aggrecan-based perineuronal nets are protected against tau pathology in subcortical regions in Alzheimer's disease. Neuroscience 2010, 169, 1347-1363. [CrossRef] [PubMed]

234. Morawski, M.; Brückner, G.; Jäger, C.; Seeger, G.; Matthews, R.T.; Arendt, T. Involvement of perineuronal and perisynaptic extracellular matrix in Alzheimer's disease neuropathology. Brain Pathol. 2012, 22, 547-561. [CrossRef] [PubMed]

235. Végh, M.J.; Heldring, C.M.; Kamphuis, W.; Hijazi, S.; Timmerman, A.J.; Li, K.W.; van Nierop, P.; Mansvelder, H.D.; Hol, E.M.; Smit, A.B.; et al. Reducing hippocampal extracellular matrix reverses early memory deficits in a mouse model of Alzheimer's disease. Acta Neuropathol. Commun. 2014, 2, 76. [CrossRef] 
236. Miyata, S.; Nishimura, Y.; Nakashima, T. Perineuronal nets protect against amyloid $\beta$-protein neurotoxicity in cultured cortical neurons. Brain Res. 2007, 1150, 200-206. [CrossRef]

237. Brückner, G.; Hausen, D.; Härtig, W.; Drlicek, M.; Arendt, T.; Brauer, K. Cortical areas abundant in extracellular matrix chondroitin sulphate proteoglycans are less affected by cytoskeletal changes in Alzheimer's disease. Neuroscience 1999, 92, 791-805. [CrossRef]

238. Suttkus, A.; Holzer, M.; Morawski, M.; Arendt, T. The neuronal extracellular matrix restricts distribution and internalization of aggregated Tau-protein. Neuroscience 2016, 313, 225-235. [CrossRef] [PubMed]

239. Holmes, B.B.; DeVos, S.L.; Kfoury, N.; Li, M.; Jacks, R.; Yanamandra, K.; Ouidja, M.O.; Brodsky, F.M.; Marasa, J.; Bagchi, D.P.; et al. Heparan sulfate proteoglycans mediate internalization and propagation of specific proteopathic seeds. Proc. Natl. Acad. Sci. USA 2013, 110, E3138-E3147. [CrossRef]

240. Yang, S.; Cacquevel, M.; Saksida, L.M.; Bussey, T.J.; Schneider, B.L.; Aebischer, P.; Melani, R.; Pizzorusso, T.; Fawcett, J.W.; Spillantini, M.G. Perineuronal net digestion with chondroitinase restores memory in mice with tau pathology. Exp. Neurol. 2015, 265, 48-58. [CrossRef]

241. Gawin, F.H.; Kleber, H.D. Abstinence Symptomatology and Psychiatric Diagnosis in Cocaine Abusers: Clinical Observations. Arch. Gen. Psychiatry 1986, 43, 107-113. [CrossRef] [PubMed]

242. O'Brien, C.P.; Childress, A.R.; Ehrman, R.; Robbins, S.J. Conditioning factors in drug abuse: Can they explain compulsion? J. Psychopharmacol. 1998, 12, 15-22. [CrossRef] [PubMed]

243. Slaker, M.; Blacktop, J.M.; Sorg, B.A. Caught in the net: Perineuronal nets and addiction. Neural Plast. 2016, $2016,7538208$. [CrossRef]

244. Slaker, M.; Churchill, L.; Todd, R.P.; Blacktop, J.M.; Zuloaga, D.G.; Raber, J.; Darling, R.A.; Brown, T.E.; Sorg, B.A. Removal of perineuronal nets in the medial prefrontal cortex impairs the acquisition and reconsolidation of a cocaine-induced conditioned place preference memory. J. Neurosci. 2015, 35, 4190-4202. [CrossRef]

245. Blacktop, J.M.; Todd, R.P.; Sorg, B.A. Role of perineuronal nets in the anterior dorsal lateral hypothalamic area in the acquisition of cocaine-induced conditioned place preference and self-administration. Neuropharmacology 2017, 118, 124-136. [CrossRef] [PubMed]

246. Blacktop, J.M.; Sorg, B.A. Perineuronal nets in the lateral hypothalamus area regulate cue-induced reinstatement of cocaineseeking behavior. Neuropsychopharmacology 2019, 44, 850-858. [CrossRef] [PubMed]

247. Xue, Y.-X.; Xue, L.-F.; Liu, J.-F.; He, J.; Deng, J.-H.; Sun, S.-C.; Han, H.-B.; Luo, Y.-X.; Xu, L.-Z.; Wu, P.; et al. Depletion of Perineuronal Nets in the Amygdala to Enhance the Erasure of Drug Memories. J. Neurosci. 2014, 34, 6647-6658. [CrossRef]

248. Tsien, R.Y. Very long-term memories may be stored in the pattern of holes in the perineuronal net. Proc. Natl. Acad. Sci. USA 2013, 110, 12456-12461. [CrossRef]

249. Duncan, J.A.; Foster, R.; Kwok, J.C.F. The potential of memory enhancement through modulation of perineuronal nets. Br. J. Pharmacol. 2019, 176, 3611-3621. [CrossRef] [PubMed]

250. Zhao, R.R.; Muir, E.M.; Nuno Alves, J.; Rickman, H.; Allan, A.Y.; Kwok, J.C.F.; Roet, K.C.D.; Verhaagen, J.; Schneider, B.L.; Bensadoun, J.-C.; et al. Lentiviral vectors express chondroitinase ABC in cortical projections and promote sprouting of injured corticospinal axons. J. Neurosci. Methods 2011, 201, 228-238. [CrossRef]

251. Bartus, K.; James, N.D.; Didangelos, A.; Bosch, K.D.; Verhaagen, J.; Yáñez-Muñoz, R.J.; Rogers, J.H.; Schneider, B.L.; Muir, E.M.; Bradbury, E.J. Large-Scale Chondroitin Sulfate Proteoglycan Digestion with Chondroitinase Gene Therapy Leads to Reduced Pathology and Modulates Macrophage Phenotype following Spinal Cord Contusion Injury. J. Neurosci. 2014, 34, 4822-4836. [CrossRef]

252. James, N.D.; Shea, J.; Muir, E.M.; Verhaagen, J.; Schneider, B.L.; Bradbury, E.J. Chondroitinase gene therapy improves upper limb function following cervical contusion injury. Exp. Neurol. 2015, 271, 131-135. [CrossRef] [PubMed]

253. Burnside, E.R.; De Winter, F.; Didangelos, A.; James, N.D.; Andreica, E.-C.; Layard-Horsfall, H.; Muir, E.M.; Verhaagen, J.; Bradbury, E.J. Immune-evasive gene switch enables regulated delivery of chondroitinase after spinal cord injury. Brain 2018, 141, 2362-2381. [CrossRef] [PubMed] 